\title{
Does Aid Promote Electoral Integrity?
}

\author{
Luca J. Uberti (University College London), David Jackson (U4 Anti-Corruption Resource Centre)
}

\begin{abstract}
Since the late 1990s, aid spending for elections has witnessed a dramatic increase. Yet, we lack a comprehensive evaluation of aid effectiveness in this particular programme area. Here, we investigate the impact of aid on electoral integrity using panel data on purpose-disaggregated aid disbursements and a multi-dimensional index of electoral quality from the Varieties of Democracy project. Based on 502 elections in 126 aid-receiving countries during 20022015, we estimate a statistically significant impact of election-support ODA on the integrity of elections. The estimated effect is, however, economically small and not very persistent. In the long run, a permanent increase in aid spending by one million US\$ leads to an improvement in electoral quality of 1.4 per cent of a standard deviation on the integrity index. We also find that different dimensions of electoral integrity are variably responsive to donor interventions. Additionally, aid spending for elections is found to be subject to declining marginal returns with respect to both aid volumes and the level of development. These findings speak to the difficulty of promoting democratic change in countries with adverse structural conditions. Still, donors may improve the cost-effectiveness of electoral assistance programmes by targeting specific countries and prioritising certain types of intervention.
\end{abstract}

\section{Introduction}

Elections are now the most common vehicle to select political leaders and legitimise executive authority. Since the Third Wave of Democratisation, the number of countries holding multiparty elections on a regular basis has increased from just over 40 in the 1980s to over 90 in the 2010s (World Bank, 2017, p. 24). Despite the global spread of electoral institutions, many low- and middle-income countries are still struggling to live up to the standards of electoral (let alone liberal) democracy. By the end of the Third Wave, only about 60 per cent of all elections around the world were free and fair, down from about 90 per cent in the 1980s (ibid.). In newly democratised countries, electoral contests are often (though not always) plagued by procedural flaws, intimidation, violence and all sorts of irregularities. Even when the incumbent refrains from the crudest forms of manipulation (ballot stuffing, deliberate vote miscounts), political parties rarely enter the contest with programmatic agendas, relying instead on vote-buying and intimidation to mobilise votes and secure an electoral majority (Wantchekon, 2003; Keefer \& Vlaicu, 2008; Mares et al., 2016).

In policy circles, democratisation is widely thought to be a necessary precondition for sustainable development and poverty reduction (World Bank, 1997; UNDP, 2002). Yet, reaping the economic and social benefits of democracy depends critically on the quality of electoral contests (Chauvet \& Collier, 2009). For this reason, donor agencies have poured an increasing share of the aid budget into democracy promotion. Since the launch of the 'good governance' agenda in the late 1990s, aid spending on electoral assistance programmes has soared from 75 million US\$ in 2002 to 728 million US\$ in 2010 (before declining again to 353 million 2016. A natural policy question to ask, therefore, is whether electoral assistance programmes have achieved their goals, bringing improvements in electoral integrity to recipient countries. Does it make sense for donor agencies to continue to allocate resources for electoral support? If so, what is the 'return' on investing in electoral assistance? And how can donors improve the effectiveness of election support programmes? 
Here, we investigate these questions using panel data on electoral integrity and purposedisaggregated aid disbursements. Since donors only began to systematically report disaggregated aid expenditures in 2002 (Clemens et al., 2011, p. 599), our sample includes 502 elections in 126 countries during 2002-2015. We cover all national elections that took place across all aid recipients in this time period. To measure electoral integrity, we use the indicators of electoral conduct published by the Varieties of Democracy (V-Dem) project (Coppedge et al., 2016), which offers the best balance between measurement detail and time coverage. To our best knowledge, this is the first paper to employ this novel dataset to investigate the aid-integrity nexus.

Because donors may allocate aid based on an assessment of the recipients' (past or expected) electoral conduct, we require a strategy to disentangle correlation from causation. To do so, we approximate the causal effect of aid on integrity by holding constant those country characteristics that may jointly influence voting fraud and donors' funding decisions. The identifying assumption is that the country characteristics that influence donors' decisions are fixed in the short run. In the robustness analysis, we relax this assumption, allowing for the possibility that donors may adjust aid flows in response to a change in the recipient's circumstances. Our results are robust to including a lagged dependent variable, to controlling explicitly for a large number of potential time-varying determinants of aid and integrity (including time trends), and to using lags and region-level averages as instruments for aid flows.

Based on this plausible identification strategy, we estimate a statistically significant impact of election support ODA on the integrity of elections. The magnitude of the estimated effect is, however, economically small and not very persistent. In the long run, a permanent increase in aid spending by one million US\$ leads to an improvement in electoral quality equal to 1.4 per cent of a standard deviation on the integrity index. In the conclusion, we suggest that the small size of the estimated effect may be due to the structural constraints that donors must contend with when promoting democratisation in developing countries (North, Wallis \& Weingast, 2012; Khan, 2013).

Nevertheless, we find that some specific aspects of electoral malpractice (ballot stuffing and counting irregularities) may be relatively more responsive to donors' attempts to eradicate them; that electoral assistance programmes are on average more effective if implemented closer to election day; and that election support ODA exhibits declining marginal returns with rising income levels and rising volumes of aid allocations. These findings imply that, in order to improve aid effectiveness in this particular programme area, donors should prioritise short-term interventions taking place on election day (for example, election monitoring of ballot-casting and vote-counting procedures), targeting specifically lowincome societies that currently do not benefit from electoral assistance.

This paper contributes both to existing research on aid effectiveness (Doucouliagos \& Paldam, 2009) and to the emerging literature on electoral integrity (Norris, 2013). Traditionally, the aid literature has examined the impact of aid spending on economic growth (Clemens et al., 2011) and on various dimensions of governance (Knack, 2004; Knack \& Rahman, 2007; Djankov et al., 2008; Scott \& Steele, 2011). Only recently have social scientists begun to study the impact of aid using more fine-grained measures of political (for example, corruption) and socio-economic (for example, schooling) outcomes (Charron, 2011; Dreher et al., 2008). 
The literature on aid and electoral integrity (a specific component of democratic development) is relatively less developed. An independent evaluation of the UNDP's electoral assistance programmes concluded that the agency's work contributed to strengthening the capacity of electoral management bodies (EMBs), especially in post-conflict settings (UNDP, 2012). More recently, economists have used field experiments to investigate the impact of specific electoral assistance interventions. These studies have examined, amongst others, the effect of a monitoring technology on vote-counting irregularities (Callen \& Long, 2015), the impact of an anti-violence campaign on election-related violence (Collier \& Vicente, 2013), the influence of holding town-hall meetings on the prevalence of clientelism (Fujiwara \& Wantchekon, 2013), and the ability of observer missions to deter ballot box fraud and count tampering (Ichino \& Schuendeln, 2012). By and large, this literature has shown that some of the interventions typically funded by donor agencies have a beneficial effect on integrity and voter turnout.

Experimental methods, however, cannot provide the basis for a global assessment of the effectiveness of electoral assistance. Recent studies have employed cross-sectional regressions to examine the impact of electoral assistance programmes. Based on data on aid disbursements by all official donor agencies, however, neither Birch (2011, p. 64-7) nor Norris (2015, p. 104-8) find a significant effect of donor-funded election support on the quality of electoral contests. The problem, of course, is that 'crossnational comparative evidence [only] provides a strictly limited test of [the impact of aid on integrity], since potential problems of endogeneity arise in interpreting this relationship' (Norris, 2015, p. 108). While experimental approaches achieve reliable identification at the cost of generality, cross-sectional analyses achieve generality at the cost of reliable identification.

In an attempt to negotiate this trade-off, this paper exploits cross-sectional time-series variation to identify the effect of foreign aid for elections. To our best knowledge, the only paper that employs countrylevel panel data to explore a similar question is Finkel et al. (2007). Using data on aid spending for democracy by USAID, Finkel et al. (2007, pp. 433-5) find a positive impact of funds allocated towards "elections and political processes" (a component of democracy aid) on an index of free and fair elections. Identification, however, is based on aid spending by a single donor agency. More importantly, their regressions (in their Table 5) do not include country FE, so that their estimates cannot rule out the potential biasing influence of unobserved country-level factors. Lastly, a focus on the 1990s makes the paper somewhat outdated. Our study extends Finkel et al. (2007) in several ways: 1. By focusing more extensively on a particularly important aspect of democracy, namely the quality of electoral processes, 2 . By using data from all foreign aid donors, 3. By attempting to account for the endogeneity of donors' decisions to commit funds to electoral assistance, and 4. By updating the analysis to the 2000s.

The paper is organised the follows. The next section discusses the notion of electoral integrity, the typical forms of electoral manipulation observed in newly democratised countries and the nature of donor interventions designed to deter malpractice. Section 3 presents the data. Section 4 sets out the model and identification strategy, while sections 5 and 6 discuss the empirical results. Section 7 concludes by drawing out some policy implications of our findings. 


\section{From Electoral Assistance to Integrity Outcomes}

To describe the extent to which elections abide by democratic principles, scholars and analysts have used terms such as 'free and fair' elections, 'electoral quality' and 'electoral integrity'. In this paper, we understand all these terms as equivalent, although for convenience we focus on the notion of 'integrity'. Electoral integrity refers to "contests respecting international standards and global norms governing the appropriate conduct of elections' (Norris, 2015, p. 4). Standards and norms are based on international legal instruments (Tuccinardi, 2014). ${ }^{1}$

\section{[Table 1]}

In low- to middle-income societies, electoral contests are often riddled by violations and irregularities. Following Schedler (2002), Table 1 presents a map of electoral integrity norms. For each norm, we also present a list of common violations. The integrity of an electoral contest may be undermined in various ways, reflecting the multi-dimensional and composite character of the notion of electoral quality. In particular, we focus on three levels at which electoral integrity may be compromised.

At the level of political agents, incumbent politicians may restrict the entry of political organisations into the electoral arena, spuriously barring opposition candidates from running, starving them of resources or severing the communication links between contestants and voters. Alternatively, the incumbent may skew the playing field in its favour by preventing opposition rallies or siphoning off government resources to finance its campaign. In the most extreme cases, it may insulate key elective offices from genuine electoral competition, allowing only limited contestation under the aegis of an authoritarian coalition (Khan, 2013).

At the level of preferences, both incumbent and contestants may engage in vote-buying, effectively denying citizens the right to freely formulate and express their political preferences. The incumbent (or, less frequently the contestants) may also exploit its control of the state bureaucracy and security apparatus to intimidate opposition voters or mobilise votes by coercion. Acting on behalf of their political sponsors, the owners or managers of politically connected firms may also pressure or intimidate their workers to vote for a particular candidate (Mares et al. 2016).

At the level of outcomes, the incumbent may manipulate the process of casting, counting and aggregating ballots in a variety of ways - by stuffing ballot boxes; destroying or manipulating votes cast, deliberately miscounting the votes, tampering with the vote aggregations, and so on. In the most extreme cases, it may refuse to step down if the outcome of the election is not favourable.

What do aid agencies typically do to address these problems and transform electoral processes in recipient countries, and what is the rationale behind their approach? A review of donors' programming documents reveals that electoral assistance strategies are premised on a three-pronged diagnosis of electoral misconduct. First, rules and procedures (voter registration systems, the laws governing the Election Management Body, or EMB) may be missing, vague or faulty. Second, when rules and procedures are notionally in place, their enforcement may be deliberately weak or absent altogether. Third, even when the political will exists to respect the rules of the game, the technical capacity of the relevant actors may be 
insufficient to accomplish this task. On this account, electoral malpractice may result from deliberate manipulation but also from knowledge or capacity deficits. Typically, electoral assistance programmes seek to address both aspects of electoral malpractice. In addition, these two aspects are difficult to separate theoretically: lack of capacity (for example, an understaffed EMB) may facilitate political interference, which may further hollow out capacity. For these two reasons, we do not restrict our analysis to issues of elite manipulation, as other authors have done (Bishop \& Hoeffler, 2016).

Corresponding to these three potential sources of misconduct (rules, enforcement, capacity) are three broad types of intervention: establishing or improving electoral rules and regulations; strengthening the capacity and independence of enforcement organizations (electoral management bodies, courts and so forth); building the capacity of civil society to monitor and report on elections. An additional but closely related set of interventions aims to empower citizens to exercise their (passive and active) electoral rights, for example, by training political or community leaders and/or increasing voters' electoral participation, especially amongst marginalised groups such as women and youth.

The mix of interventions typically employed to address a given violation, and thereby advance or safeguard the corresponding integrity norm, is presented in Table 1. A brief review of electoral assistance programmes provides some illustration. Focusing on the agents of electoral contests, for instance, a USAID-funded programme in Bangladesh sought to increase compliance with campaign finance laws by strengthening the analytical capacity of government bodies to audit candidate filings (USAID, 2015, p. 4). In Nigeria, a European Union (EU) funded project sought to improve the functioning of the EMB by supporting the establishment of effective internal rules (EU Commission, 2014, p. 6; see also DFID, 2013). Focusing on voter preferences, the same project in Nigeria sought to promote women's political empowerment by facilitating targeted legal reforms to promote gender-based affirmative action and combat family voting (EU Commission, 2014). Regarding the outcome of electoral contests, both these programmes sought to build the capacity of civil society and media groups to monitor and report on the contest - for example, by funding domestic election monitors or training media practitioners on issue-based coverage of elections.

Of course, many of these activities cut across the operational strategies and integrity outcomes identified above. Some of them also target different dimensions of integrity simultaneously. For this reason, there is no unified 'theory of change' underpinning electoral assistance programmes. Each type of intervention is expected to improve one (or more) specific integrity outcomes through a distinct causal mechanism. For instance, a voter education campaign may empower vulnerable groups to exercise their franchise, while international monitors may contribute to deterring vote counting irregularities on polling day. At the same time, different dimensions of integrity may reinforce each other. For instance, building the capacity and integrity of the Electoral Management Body (EMB) may indirectly improve the quality of voter registration. Similarly, promoting fairness in access to broadcast media may empower political actors with a programmatic agenda and thereby reduce the incidence of vote-buying.

In general, donor interventions seek to empower domestic agents of change (voters, political parties, social movements and public agencies) as a means to transform the electoral process in the recipient country. Their actions are premised on the notion that agency matters for democratic change 
(Finkel et al., 2007). But does it? Does aid-funded electoral assistance work? We now turn to exploring this question empirically.

\section{Data}

This section describes the data used to measure our two main variables: ODA spending on electoral support and electoral integrity. The key difficulty concerns the measurement of our dependent variable electoral integrity. Several options are reviewed and discussed by Norris (2015, pp. 29-36). Existing datasets either provide detailed information for a small number of elections ${ }^{2}$, or cover a large number of elections in relatively little detail ${ }^{3}$. Yet others provide just an overall indicator of electoral quality for a relatively limited number of elections ${ }^{4}$.

A solution to the trade-off is offered by the Varieties of Democracy (V-Dem) dataset (Coppedge et al. 2016), compiled by the University of Gothenburg (in Appendix C, however, we show that our core results are robust to using an alternative indicator of electoral integrity). The V-Dem dataset provides a (perception-based) indicator of free and fair elections for most countries in the period 2002-2015 (v2elfrfair). ${ }^{5}$ Furthermore, a number of additional indicators focus on specific dimensions of electoral quality. Unlike v2elfrfair, these component measures do not require expert-coders to 'mentally' aggregate over the multitude of conditions required for a free and fair election. Individually, they provide a less general but arguably more 'objective' assessment of electoral quality ${ }^{6}$. Thus, rather than leaving the job of aggregation to the expert-coders, we constructed an index of electoral integrity by aggregating the individual components 'mathematically'.

\section{[Table 2]}

We proceeded in two steps. In the first instance, we singled out all the V-Dem indicators that correspond to one or more of the dimensions described in Table 1. This procedure led us to select 13 relevant indicators, which are described in detail in Table $2 .^{7}$ These variables measure various dimensions of integrity that pertain to the agents of elections (opposition parties' access to broadcast media), the formulation and expression of political preferences (the incidence of vote-buying), and the aggregation of preferences into an election outcome (the incidence of voting irregularities). The questions are formulated very precisely. For instance, the question used to construct v2elirreg clarifies that 'examples [of voting irregularities] include use of double IDs, intentional lack of voting materials, ballot-stuffing, misreporting of votes, and false collation of votes', and that 'this question does not refer to lack of access to registration, harassment of opposition parties, manipulations of the voter registry or vote-buying', which are dealt with in separate questions (V-Dem, 2017, p. 95). The expert coders provide a rating on a 5-point scale ranging from 0 to 4 . A rubric provides explanations for each item on the ordinal scale.

The variables are coded for specific electoral contests, so years without elections are dropped. ${ }^{8}$ This leads to 502 observations (election years) during 2002-2015. Each election year is coded by a minimum of 
five independent experts, most of whom are native to the countries that they code. A Bayesian item response model is used by V-Dem to aggregate the experts' ordinal ratings and estimate a latent continuous variable, taking coder characteristics, biases, and cross-coder reliability into account (Pemstein et al. 2015). ${ }^{9}$ Besides allowing for estimation by simple OLS, a continuous variable provides richer information than other indicators of electoral quality, which are typically reported on an ordinal-response (the Freedom House Electoral Processes index) or a binary (Bishop \& Hoeffler, 2016) scale.

Next, to reduce the number of dependent variables, we performed a factor analysis. We employed a principal-component method to estimate the pattern matrix. To aid the interpretation of the factor scores, we also implemented a promax rotation of the matrix elements (Hamilton 2013, p. 140). The analysis extracts two latent factors with an eigenvalue greater than 1, integ1 and integ2, which explain 51 and 44 per cent of the common variance between the $13 \mathrm{~V}$-Dem indicators, respectively. ${ }^{10}$

A loading plot of the partial correlations between integ1 and integ2 and the $13 \mathrm{~V}$-Dem indicators is displayed in Figure 1. The indicators that load heavily on integ2 pertain to the general quality of electoral institutions, such as the ability of opposition parties to enter the political arena and run an election campaign. The measures that are more highly correlated with integl, by contrast, refer to more subtle strategies that the incumbent may adopt to ensure its political survival - for instance, buying votes or rigging the vote-counting process. These two aspects of electoral integrity are conceptually distinct. The incumbent may resort to a clientelist strategy of political mobilisation, and/or ballot stuffing, even in the presence of an otherwise open field of political contestation (Keefer \& Vlaicu 2008; Khan 2013). Similarly, the incumbent may adopt a more programmatic strategy of electoral mobilisation, and refrain from the most egregious types of vote-counting fraud, while de facto restricting access to the political arena (as is perhaps the case in Russia). In our sample, integ1 correlates with integ2 at 0.42 . Both indicators are highly correlated (at 0.78 and 0.76 , respectively) with $v 2$ elfrfair, the expert-coders' overall perception of freeness and fairness ${ }^{11}$, and with a simple arithmetic average of our 13 indicators (at 0.86 and 0.83 , respectively). Our two indices of electoral integrity are also positively correlated ( 0.65 and $0.81, \mathrm{~N}=391)$ with the Freedom House (FH) measure of Electoral Processes (EP) and with Bishop \& Hoeffler's (2016) dichotomous measures of 'free' $(0.49$ and $0.52, \mathrm{~N}=213)$ and 'fair' elections $(0.39$ and $0.42, \mathrm{~N}=213)$.

[Figure 1]

To measure electoral assistance, we use data on aid spending reported by the OECD. The OECD data allow us to disaggregate aid volumes by project purpose and isolate the aid flows specifically directed to electoral assistance, rather than democracy promotion, good governance or development assistance more generally. This category includes aid flows designed to support 'electoral management bodies and processes, election observation and voters' education' (OECD, 2018). Additional details on this variable can be found in Appendix A.

The assumption (ubiquitous across all areas of the aid literature) is that aid expenditures proxy for the extent and intensity of donor interventions. Donors allocate financial resources in order to generate impact: they would like each democracy dollar to have a material effect on the quality of recipient 
countries' elections. ${ }^{12}$ Thus, if donors' electoral assistance strategies are effective, we should expect a positive association between donor funding and electoral integrity levels.

The OECD aid data pool together aid spending by all donors - bilateral and multilateral, DAC and non-DAC. ${ }^{13}$ In 2015, 29.7 per cent of aid spending for elections came from multilateral donors - chiefly, the EU and, within the UN system, the UNDP. The remaining portion originated from bilateral donors principally the US, which provided some 50 per cent of all bilateral aid for elections, and the UK which contributed 17.7 per cent. ${ }^{14}$ All these agencies espouse similar conceptions of 'electoral integrity' and draw from the same toolkit of interventions in their efforts to promote it. Although each donor may employ a slightly different mix of interventions on the ground, we conduct our analysis from the point of view of the 'average donor', a common approach in the aid literature.

[Figure 2]

Trends in aid spending for election support during 2002-2015 are summarised in Figure 2. Election support ODA increased dramatically during 2002-2010, to then decline slightly in the wake of the global financial crisis. During 2002-2015, donors have spent an aggregate total of 5.1 billion US\$ election support activities in developing countries. On the recipient side, election-related ODA amounts to an average influx of $2.9 \mathrm{mln}$ US\$ per country per year (st.dev. = $11.9 \mathrm{mln}$ US\$). Spending on electoral assistance programmes rises to $5.2 \mathrm{mln}$ US \$ during election years (st.dev. $=18.5 \mathrm{mln}$ US\$), indicating that most (51.4 per cent) aid for electoral assistance is disbursed in the runup to elections, rather than in-between successive contests. Some of the top aid recipients in this programme area are also aid-dependent countries more generally, such as Afghanistan, DRC, Sudan and Haiti.

In addition, Figure 2 reports the average level of electoral integrity across all aid recipients during 2002-2015. Over this time period, total spending for election support by all donors correlates positively with the mean of integ1 (coeff. $=0.22$ ) and integ2 (coeff. $=0.35$ ) across aid recipients. Lagging the aid variable by one year increases the correlation between ODA and integl to 0.43 . Of course, this association cannot be given a causal interpretation. To better examine the impact of aid on integrity, we employ panel regressions.

\section{Model and Identification Strategy}

We estimate the following OLS model with fixed effects (FE):

$$
I_{i t}=\alpha_{0} \ln O D A_{i t}^{\text {elect }}+\alpha_{1} \ln O D A_{i t(-1)}^{\text {elect }}+\boldsymbol{\varphi} X_{\mathrm{it}}+\varphi_{i}+\tau_{t}+u_{i t}
$$

where $I_{i t}$ is either integ 1 or integ 2 for country $i$ in election year $t$; $\ln O D A_{i t}^{\text {elect }}$ refers to total ODA disbursements for electoral assistance (in logs) in the year in which the election is held; and $\ln O D A_{i t}^{\text {elect }}(-1)$ and $\ln O D A_{i t(-2)}^{\text {elect }}$ denote ODA spending (in $\operatorname{logs}$ ) one year and two years before election year $t$, 
respectively. A distributed-lag model allows for electoral assistance programmes implemented up to two years prior to an election to influence the quality of the contest. Further, $\boldsymbol{X}_{i t}$ is a vector of time-varying controls, $\varphi_{i}$ and $\tau_{t}$ are country and year fixed effects, and $u_{i t}$ is an independently distributed random disturbance. A full description of the variables is provided in Appendix B.

We take the log of ODA flows since this variable has an extremely right-skewed distribution owing to a large fraction (27\%) of zero values - that is, election years in which donors provided no electoral assistance. The distribution of the integrity index, by contrast, is highly normal. Since we are interested in the impact of donor programmes on national elections (parliamentary and presidential), we assume that what matters from the point of view of the outcome is the total volume of aid devoted to electoral assistance, rather than the level of ODA per capita (see also Finkel et al., 2007: 431-3). Running a free and fair election depends critically on the honesty and capacity of central-level institutions (the EMB, the supreme court, and so forth) and the political will of the national incumbent. These conditions are equally binding in small and large countries. Since, however, larger countries may face additional technical and logistical challenges (for example, organising and staffing polling stations in remote regions), we also examine the relationship between integrity and ODA per capita. ${ }^{15}$

Our main parameters of interest are the $\alpha$ 's, which are expected to be positive if aid promotes integrity. But is evidence of a positive relationship sufficient to establish causality? The main threat to inference is the possibility that aid decisions may be endogenous to electoral quality. Donor interventions are not randomly assigned as donors may allocate aid for elections based on recipients' need (Hoeffler \& Outram, 2011). Specifically, donors may first observe a set of country characteristics (level of development, degree of political contestation) that are known to make electoral contests prone to irregularities, and then allocate more resources to countries with a higher expected risk of electoral fraud. When committing resources to subsequent elections, donors may also take into account the integrity standards attained in the country's previous polls. In their strategic assessments, for instance, USAID notes that 'each country's unique history and political evolution define opportunities and obstacles in the transition to democracy', with these factors providing the basis to 'target democracy dollars' (quoted in Finkel et al., 2007: fn. 29, emphasis added). If donor agencies allocate more resources towards fraud-prone countries, the OLS estimator is biased downwards. ${ }^{16}$

Besides performance in past elections, donors may also observe other country characteristics that, in their estimation, make voting fraud more likely. Several complementary explanations of electoral malpractice, some of which may inform donors' funding decisions, are discussed by Norris (2015). She delineates three broad drivers of electoral integrity and malpractice. These relate to socio-economic structure, international forces and domestic institutions. First of all, electoral integrity may be subject structural constraints, including the country's level of development, its dependence on natural resource exports, and the ethno-religious make-up of the society (Bernhard et al., 2004; see also Treisman, 2000). In line with modernisation theory, electoral integrity is most likely to be achieved in more industrialised societies, where higher urbanisation and literacy rates are likely to foster the emergence of an affluent middle class and a robust culture of civic associationism (Boix \& Stokes, 2003). Second, international forces (other than development aid and monitoring missions) may loom large in shaping the quality of 
domestic elections. Membership in international organisations and treaties, for instance, may facilitate norm diffusion. Similarly, the quality of electoral democracy in a country may be subject to regional spillover effects - both positive (the influence of the EU in the former accession countries of Central and Eastern Europe) and negative (the influence of Russia in the post-Soviet republics). Lastly, the quality of electoral institutions (the electoral code) and organisations (political parties, civic groups) are likely to be a proximate determinant of electoral integrity. Institutions and organisations are also the main target of electoral integrity programmes: they are the levers or channels through which donor funding is supposed to engender democratic change (Finkel et al. 2007). ${ }^{17}$

In our baseline models, we first control for the influence of these confounding factors by including country fixed effects - an approach also favoured by Finkel et al. (2007: 425-7). The rationale behind this approach is twofold. First, while many of these factors are not time-invariant, they actually change very slowly over a short time span of 15 years. For instance, in our dataset only 1.9 per cent of the total variance in income levels is due to variation over time, while the remainder results from broad differences in levels of development between countries. Once large country-level differences are held constant, any residual variation over time may be expected to have little influence on either electoral integrity or donors' aid allocation decisions. ${ }^{18}$ By contrast, the sharp increase in aid spending for electoral assistance in the course of the 2000s generates substantial variation over time in our main variable of interest. As much as 33.4 per cent of the total variance in $\ln O D A_{i t}^{\text {elect }}$ (during election years) results from within-country variation.

Second, not only are many of these risk factors slow-moving, but donor agencies also update their expectations of electoral malpractice (based on these factors) rather infrequently. Annual risk assessments are usually only required for very large projects. Furthermore, such assessments typically focus on feasibility considerations rather than need (or merit). Over a reasonably short time span, decisions to allocate aid are likely to be informed primarily by broad differences between countries. For these two reasons, we feel safe in assuming that, once country-level heterogeneity is held constant, the time component of variation in aid volumes may be viewed 'as if' it was random and thus uncorrelated with the error term. In our baseline models, identification is based on this (arguably exogenous) source of time variation in aid flows.

There are two main advantages from this approach to identification: first, we avoid losing observations due to potential missing values in the control variables; second, we estimate a parsimonious specification that greatly reduces the risk of misspecification error. In the robustness analysis, however, we relax the assumption that the within-country variation in aid flows over time is exogenous. To allow for donors to update their allocative decisions based on past electoral performance or other changing country characteristics, we present three additional sets of results: we estimate a dynamic panel model with a lagged dependent variable; explicitly control for a large number of potential join determinants of aid and integrity; and use deeper lags of aid and region-level averages to instrument for aid disbursements.

Of course, a control-function approach cannot fully account for unobserved time-varying heterogeneities. At the same time, instrumental-variable (IV) estimation is subject to contentious assumptions of instrument validity. Despite these inherent limitations, we believe that our results are very close to measuring the causal impact of aid-funded programmes on integrity outcomes. 


\section{Baseline Results}

The baseline estimates of eq. (1) are presented in Table 3. As a benchmark, column 1 reports a pooled OLS model with no country FE, while models 2-3 include country FE. ${ }^{19}$ Panel A (B) reports regressions for integ1 (integ2). In the pooled regression for integl (but not for integ2), ODA is negatively related to integrity, potentially reflecting the targeting of aid dollars to countries with a higher prevalence of electoral irregularities. Consistent with our expectations, the failure to account for potential determinants of donors' aid decisions yields an estimator of the aid effect that is biased downwards. Yet the fact that aid is positively associated with integ2 suggests that, while donors may allocate aid based on the prevalence of vote-buying and counting irregularities, they may not do so based on a more general assessment of the quality of electoral democracy.

Controlling for potential joint influences on aid and integrity, the models in column 2 find a positive and statistically significant effect of aid on integrity, whether the latter is measured by integl or integ2. As can be seen by inspecting a conditional scatterplot (Figure 3), this positive relationship holds quite uniformly in the data and is not driven by outliers. Models 3 allow for the quality of an election to be influenced by aid-funded programmes implemented a year before the contest. ${ }^{20}$ Election-year spending has a slightly larger effect on the integrity of the ensuing contest (when the latter is measured by integ2) than aid spent in the first year preceding the election. That said, a Wald test cannot reject the equality of these two coefficients at conventional levels $(p$-value $=0.145){ }^{21}$

\section{[Table 3]}

[Figure 3]

Although statistically significant, the magnitude of the estimated effect of aid on integrity is economically small. Model 3, Panel A (B) implies that, on average, doubling aid spending for elections ${ }^{22}$ improves electoral integrity by 2.7 (3.6) per cent of a standard deviation of integ1 (integ2) if the additional spending is disbursed in the election year, or 2.6 (1.3) per cent of a standard deviation if it is disbursed one year prior to the contest. The total impact of election-support aid disbursed prior to an election $\left(\alpha_{0}+\alpha_{1}\right)$ is the same whether we measure integrity outcomes with integ $1(0.42, p$-value $=0.002)$ or integ2 $(0.46, p$ value $=0.002$ ). Overall, donor-funded electoral assistance explains around 10 per cent of the total variation over time in electoral integrity within countries.

A more intuitive way to interpret the results is to consider the impact of each additional dollar spent. ${ }^{23}$ Because of the (lin-log) functional form of the aid-integrity relationship, the effect of the marginal dollar decreases non-linearly in the volume of aid (Figure 4). For the average aid recipient (vertical line in Figure 4$)^{24}$, an additional million US\$ disbursed during an election (pre-election) year, which corresponds to 5.2 (6.5) per cent of a standard deviation of ODA spending, is followed by an improvement in electoral integrity equivalent to $0.49(0.70)$ per cent of a standard deviation of integl. The impact of aid spending for election support (by all donors during the 2000s) is larger in standardised terms than the overall effect of 
USAID's democracy programmes estimated by Finkel et al. for a sample covering the 1990s (2007: 424), but still quite small. The standardised coefficient of (the log of) election-year ODA spending is 0.09 in the regression for integl and 0.13 in the regression for integ2, implying that a standard-deviation increase in donor funding for electoral assistance induces a $0.10(0.13)$ standard-deviation improvement in electoral integrity.

[Figure 4]

Column 4 reports an alternative specification of the baseline model that uses the log of ODA per capita instead of total aid flows as the measure of electoral assistance. While this variable enters positive and significant, its first lag is now statistically insignificant, indicating that country size may only be consequential for the effectiveness of those components of electoral assistance (for instance, election monitoring) that are implemented close to polling day. ${ }^{25}$ The explanatory power of this model, however, is less than half of that of the corresponding models with electoral assistance defined as total ODA spending.

[Table 4]

A question that should be of particular concern to donor agencies is which particular aspects of electoral integrity are most amenable to reform. Although we do not have data that further disaggregate election aid spending by sub-components, answering this question allows us to speculate as to which particular intervention techniques are most effective. To do so, we estimate versions of model 3 from Table 3 using the 13 sub-components of electoral integrity separately as dependent variables. The point estimates and standard errors from these 13 regressions are reported in Table 4. For comparison, we also reproduce the regression models with the integ1 and integ 2 scores on the left-hand side. In line with our previous findings, the parameter estimates are generally larger for election-year ODA than its first lag. Election-year interventions are particularly effective at strengthening the autonomy of the EMB, containing government intimidation, pre-empting voting irregularities and ensuring access to broadcasting media for interest groups and, to a lesser extent, election candidates. ODA spending in the year preceding the election is also estimated to have a beneficial effect on electoral violence, party bans and the likelihood of election results being accepted by the incumbent, although by far the strongest impact of once-lagged ODA is, again, on EMB autonomy and voting and counting irregularities taking place on election day.

These results resonate with previous findings. Bishop \& Hoeffler (2016), for instance, argue that the counting of votes is a much less problematic aspect of elections than the campaign process. In a preliminary analysis based on pooled data for the period 1975-2011, they also find that total aid spending (as opposed to election-support ODA) has a larger beneficial impact on polling-day events than on the process leading up to the election. Although suggestive in nature, these results indicate that, to increase value for money, donors should focus their efforts on interventions targeting voting and counting irregularities. Of course, practitioners should simultaneously develop imaginative ways of attacking the other, seemingly more intractable, dimensions of electoral malpractice (EMB capacity, electoral violence, 
and so forth). Given the existing toolbox of interventions, however, aid effectiveness may be maximised by focusing on polling-day irregularities.

\section{Robustness and Extensions}

A potential concern with our regressions is that the country FE may not completely purge the influence of other potential co-determinants of aid and integrity. Some of the most important drivers of democratic quality (the level of development) are not time-invariant. If donors observe this (unmodelled) variation when making funding decisions, our estimates of the impact of aid on integrity would still be subject to downward bias. Similarly, aid donors may decide how much to spend in support of a given election after observing the integrity standards achieved by that country in the previous electoral contest. This would, again, produce downwardly-biased estimates of the aid coefficient.

\section{[Table 5]}

To allay the latter concern, we estimate dynamic models that include a lagged dependent variable (Table 5). These models reflect the possibility that the integrity levels achieved in a given election may become entrenched or institutionalised, persisting through to the next election. As a benchmark, column 1 reports a static model along the lines of Table 3, model $3 .{ }^{26}$ Column 2 conditions on the integrity levels achieved in the previous contest (which might have taken place a year before or several years prior). Although electoral integrity does seem to be persistent, the average 'rate of accumulation' of integrity norms is quite low. Less than 30 per cent of the integrity levels achieved in a given contest carry over 'automatically' to the next contest. Since elections may be spaced apart by several years, intervening events might undermine the gains achieved in the previous contest, lowering the quality of the subsequent election. The fact that the integrity norms transplanted by donor agencies are not very 'sticky' raises questions about the sustainability of aid-funded electoral assistance programmes.

Focusing now on the main variable of interest, we note that the magnitude of the aid coefficients in the dynamic model actually declines slightly. In fact, in the regression for integ2 (model 2, panel B) the first lag of ODA loses statistical significance ( $p$-value $=0.299$ ). This finding suggests that, far from being biased downwards, the static OLS estimator returns an optimistic estimate of the impact of aid on integrity.

The dynamic model may also be used to derive estimates of the long-run effects. ${ }^{27}$ The long-run effect takes into account not only the impact of aid spending today, but also the compounding effect of the aid allocated towards previous electoral contests, which influence the quality of today's elections through a norm persistence channel. Based on model 2, a permanent increase in aid spending by 1 million US\$ (which corresponds to 5.2 per cent of a standard deviation of ODA spending) leads to a long-run improvement in electoral integrity equivalent to 1.4 per cent of a standard deviation of the integrity index ( $p$-value $=0.002)$. This is still a rather small effect that is not substantially higher than the corresponding short-run impact estimated in the preceding section. 
Since the estimates in column 2 may be subject to the well-known problem of dynamic panel bias (Nickell, 1981), model 3 instruments for the lagged dependent variable (the integrity levels of the previous contest) using a twice-lagged measure of integrity (the integrity of the next-to-last contest). Doing so ensures that the estimator is consistent (Anderson \& Hsiao, 1982). The point estimates from the IV regression are very close to the corresponding OLS coefficients, although (as expected) they are less precisely estimated.

Lastly, the models in column 4 regress integrity on aid after netting out the countries' underlying trends in electoral integrity outcomes. If donors punish or reward countries trending in particular ways on the dependent variable, and the time trends are omitted from the regression, our estimates of the aid effect may be severely biased. The results, however, are robust to including country-specific trend terms.

[Table 6]

Even if donors do not assess the quality of past elections (or the country's recent integrity trends) when allocating funds, they may observe time-varying factors that make a forthcoming contest more vulnerable to manipulation. The models in Table 6 allow for this possibility by including a range of additional controls, which are described in detail in Appendix B. Following the theoretical framework presented by Norris (2015, see also discussion in section 4), the variables fall in three broad categories: structural constraints, international forces and domestic institutions. Model 1 is a benchmark model that also includes time-period fixed effects to control for trends in electoral integrity affecting all countries simultaneously (in most specifications, however, the time FE are jointly insignificant at the 5 per cent level). Model 2 controls for the log of GDP per capita, which stands for a broad range of structural constraints on the viability of free and fair elections ( education levels, size of the middle class, resources available to finance rule enforcement) ${ }^{28}$ Controlling for time variation in income levels around the country mean, however, does not change the magnitude of the estimated ODA coefficients, indicating that our estimates are unlikely to be subject to substantial downward bias once fixed country-level characteristics are accounted for.

Models 3 control for a range of international forces that may have an impact on the quality of electoral competition (Gleditsch \& Ward, 2006). Specifically, it includes the KOF index of political globalisation (measuring the extent to which a country is integrated into the system of international organisations and treaties); a measure of the average regional level of electoral integrity for a given year, as a proxy for regional norm diffusion ('democratic domino') effects; and a dummy for whether the contest was monitored (also) by Western observer missions, which may be expected to uphold the norms of electoral integrity with greater alacrity. Models 4 control for three additional political and institutional measures: the number of years the executive has been in office at the time of the election (as a proxy for the degree of political contestation); the number of years since the country's political independence (as a proxy for the depth of institutional consolidation); and a rule-of-law index from the World Bank (as a proxy for judicial independence). Lastly, column 5 reports 'kitchen sink' models that include all control variables simultaneously (together with a measure of natural-resource dependence, for which we only have a limited 
number of observations). In both the regressions for integ1 and integ2, the coefficient on election-year ODA spending loses statistical significance. Yet, running a benchmark model on the same restricted sample of 204 elections (column 6) reveals that the loss of significance is entirely due to reduced sample size, rather than the inclusion of additional covariates. In fact, omitting the potential co-determinants of aid and integrity included in column 5 causes the magnitude of the ODA coefficients to decline slightly.

Across models 2-6, the inclusion of additional regressors leaves our results qualitatively unaltered, suggesting that our estimates are not particularly sensitive to the omission of time-varying observables. These results contrast with those reported in Table 3 (Panel A), where the omission of country fixed-effects was shown to lead to a severely downwardly biased estimator of the ODA coefficients. Donors' funding decisions are indeed affected by country-specific risk factors. Yet, in the short run donors are unlikely to review their budget allocations in response to changing country characteristics.

In an alternative specification (not reported in full) ${ }^{29}$, we also interacted the ODA variable with the $\log$ of GDP per capita. This is to allow the level of development to exert a moderating influence on the magnitude of the aid effect. Aid recipients are a highly heterogeneous group of countries including anything from least developed economies (Haiti) to more industrially advanced middle-income economies (Argentina). It is plausible that structural conditions, as proxied by income levels, may not only exert a direct influence on the quality of electoral democracy, but also create different opportunities and constraints for donor agencies, and hence different payoffs from allocating resources to electoral assistance programmes.

\section{[Figure 5]}

Figure 5 reports the conditional marginal effect of election-support ODA on integrity (as measured by integ1) at different levels of development. ${ }^{30}$ Although electoral assistance is never estimated to be detrimental for electoral democracy (at statistically significant levels at least), the results suggest that election-year programmes (left panel) may be subject to decreasing marginal returns as an aid recipient develops economically. The same is true, albeit less starkly, for pre-election year spending (right panel). The integrity gain from doubling aid spending in a country with an income level of 403 US\$ per capita $(\approx \exp 6)$ is over twice as large as the gain from doubling aid spending in a country with a GDP per capita of 2980 US\$ $(\approx \exp 8)$, and the difference is statistically significant at the 5 per cent level ( $p$-value $=$ 0.037). For income levels higher than 4600 US\$ per capita (that is, in upper-middle income economies, using the World Bank classification), the effect on integl of doubling aid spending becomes statistically indistinguishable from zero. A possible explanation for this finding is that, although higher-income economies face fewer constraints on democratisation, the structural forces that enable greater electoral integrity, such as the rise of an educated middle class, completely override the impact of external interventions, driving down their marginal effect. 
A lingering concern with our estimates is that controlling for time-varying observables cannot completely eliminate the risk of omitted variable bias. Aid decisions and integrity outcomes may co-evolve as a result of unobserved processes. Specifically, if donors adjust their spending in response to unobserved developments in recipient countries, reallocating resources towards countries that develop new needs, our estimates are still biased downwards. We explicitly address this possibility by estimating instrumentalvariable (IV) models (Table 7).

To reduce multicollinearity in the second-stage equation, we instrument for election-support ODA (Part A) and its first lag (Part B) in separate regressions. ${ }^{31}$ Our instrument for aid decisions is the average level of aid spending in the country's geographical region for a given year (excluding the country's own aid inflows from the regional average). This variable proxies for the geopolitical priority that donors accord to a given region, and is positively correlated with our aid variable (coeff. $=0.42$ ). The identifying assumption is that Western donors' geopolitical considerations only influence a country's electoral-integrity outcomes indirectly by determining the volume of aid to that country. That said, the aid captured by a given geographical region may also influence the average quality of electoral processes in the region. In turn, the quality of elections in a country's neighbourhood may affect a country's electoral integrity through a normdiffusion mechanism. To block out this indirect channel (which would invalidate our instruments), all our regressions include the average regional level of electoral integrity (excluding the country's own measure) as an additional exogenous regressor. When the endogenous variable is the first lag of ODA, we also use the second lag of ODA spending as an additional instrument to increase the precision of the IV estimator.

Columns 1 and 4 report the OLS benchmarks, which are qualitatively consistent with previous findings. Models 2 (and 5) treat (the first lag of) election-support ODA as endogenous, and columns 3 and 6 report dynamic models that control for the level of integrity attained in the previous electoral contest. Since Kleibergen-Paap's F-test of instrument significance always exceeds the critical value, we reject the null of weak identification. For the over-identified models (columns 5 and 6), a Hansen J-test cannot reject the null that the instruments' exclusion restrictions are jointly valid.

In the regressions for integl (Panel A), the IV estimate of the effect of aid on integrity is generally larger (up to twice as large in model 2) than the corresponding OLS estimate. ${ }^{32}$ This finding suggests that our results so far may indeed be subject to downward bias and should be interpreted as a lower bound. In the regressions for integ2 (Panel B), by contrast, the IV estimates are generally lower (typically close to zero for the first lag) and statistically insignificant, particularly in the dynamic specifications. In sum, OLS might overestimate the beneficial effects of aid on the general quality of electoral institutions - for instance, the ability of opposition groups to access the political arena and communicate a political message. At the same time, OLS might underestimate the alleviating impact of aid on the incidence of electoral misconduct, such as vote-buying or ballot miscounts. Nevertheless, the IV results should be interpreted with caution: in all the models reported in Table 7, a Durbin-Wu-Hausman test fails to reject the null (at the $5 \%$ level) that aid may be treated as exogenous. This results indicates that the IV estimates are not systematically different from the corresponding OLS estimates. It also lends additional credence to our identifying assumption that, once FE are included, the time component of aid variation may be regarded 'as if' randomly assigned. 


\section{Discussion and Conclusion}

This paper provides novel insights into one particular aspect of donor agencies' work in developing countries: namely, electoral assistance. Due to data limitations, existing studies rely on either cross-country regressions or field experiments to assess the effectiveness of aid-funded election-support programmes. As such, the analysis of the aid-integrity nexus is subject to a trade-off: while experimental approaches can only identify the causal impact of specific interventions, cross-sectional analyses cannot generate a reliable estimate of the global (average) effectiveness of electoral-assistance programmes. This paper has attempted to overcome the limitations of both approaches by using panel data. In contrast to previous studies, we also construct novel, multi-dimensional indicators of electoral integrity that provide substantial coverage of elections over time.

Based on a plausible identification strategy, we find that aid spending for election support exerted a positive and statistically significant influence on the quality of elections in 126 aid recipients during 20022015. The magnitude of the estimated effect is, nevertheless, economically small. In addition, our findings suggest that donor-led electoral reforms may not be very sustainable: only a small fraction of the integrity gains achieved in a given contest carry over 'automatically' to the next one. Accordingly, the long-run effect of a permanent increase in aid spending is not substantially larger than the short-run impact effect. At every election, donors must go 'back to the drawing board', so to speak, as the bulk of the progress achieved in a given election cycle does not translate into permanent changes in norms and institutions. Lastly, aid spending for elections may be subject to declining marginal returns with respect to both aid volumes and the level of development. The gains from allocating additional resources to electoral assistance are lower in more developed economies and, ceteris paribus, in countries that already receive large volumes of aid for election support.

Taken together, these results present an ambiguous picture of the role of donors in promoting democratic change. On the one hand, a statistically significant effect of aid on electoral integrity lends credence to the view that donor-funded programmes can successfully empower domestic agents of change (political institutions, social organisations, voters), enabling them to improve the quality of elections and stimulate democratic development (Finkel et al., 2007). On the other, a small and short-lived effect speaks to the difficulty of fostering democratic agency in countries with adverse structural conditions. The democratisation literature has long related the quality of democracy to the level of economic development: countries at low levels of income have both a lower probability of transitioning to democracy and, if they do transition, they face a higher risk of democratic backsliding (Boix \& Stoke, 2003).

Recent contributions have offered deeper insights into the mechanism underlying this association (North, Wallis \& Weingast, 2012). When resources are scarce, elites engineer social stability by creating 'limited access orders'. These are social arrangements that exclude nonelites and create special political and economic privileges (or 'rents') to accommodate or appease powerful groups with 'violence capacity' - that is, with the capacity to destabilise the social order. Electoral manipulation may be an important tool used by elite groups to keep out nonelites and generate 'rents' to be used for political accommodation - for instance, to include unpopular but powerful political groups into the ruling coalition. 
In this framework, externally driven democratisation efforts often fail 'because they try to transplant elements of the open access order - such as [electoral] democracy - directly into limited access orders. These reforms threaten the rent-creation that holds the society together [...]. Not surprisingly, the elite and many nonelite resist, sabotage, or subvert such reforms in limited access societies that are not ready for them' (North et al., 2007, p. 5). Even if the most overt forms of manipulation (ballot-stuffing, the subversion of the legal-formal autonomy of the EMB) may be curtailed, political competition is likely to remain non-programmatic in nature and to be structured along patron-client lines. Even in more mature limited-access societies, elections are often more akin to "processes through which the organisational strengths of competing clientelist coalitions are revealed', than to a means to 'discover the true preferences of the electorate' (Khan, 2013, p. 60). These considerations might explain why donor-led efforts to improve the integrity of elections in aid-receiving countries have produced positive but ultimately only modest results. Structure seems to be considerably more consequential than agency in driving democratic outcomes.

Of course, this is not to say that donors should abandon all efforts to promote electoral integrity in low to middle-income democracies. On the contrary, we show that external agency does have a material impact on electoral processes, however small. In fact, our findings indicate that the component of aid spending directed towards electoral support has a beneficial impact on precisely the dimension of democratic performance (electoral integrity) for which it is targeted.

Needless to say, our results represent 'average' effects, which are subject to country-specific disturbances. To minimise the risk of failure in specific country programmes, donors should always avoid 'auto-pilot' approaches to programming and tailor democracy promotion closely to the local context (Carothers, 2015). Still, our results suggest that, to maximise impact and value for money, donors (particularly those that invest heavily in electoral assistance, such as USAID, the EU and UNDP) should consider re-allocating resources to low-income countries that currently receive little funding. Donor agencies should also prioritise the fight against those aspects of electoral fraud that may be more feasibly tackled within the structural constraints of the existing 'social order' (vote-counting irregularities, government intimidation), while developing imaginative solutions to address the other, more stubborn, forms of electoral malfeasance (election boycotts, electoral violence) ${ }^{33}$

While electoral assistance programmes alone are unlikely to transform the 'deep' structural drivers of flawed and failed elections (at least if the current mix of electoral assistance strategies is held constant), other donor interventions aimed at improving economic performance and raising the overall level of economic development may also remove some of the structural constraints on democratisation and, in the long run, improve the quality of elections. This indirect effect of donor interventions on democratic outcomes may be particularly relevant in higher-middle income economies, where the marginal effect of electoral assistance is generally lower. It also remains an important area for future research. 


\section{References}

Alesina, A., \& Weder, B. (2002). Do Corrupt Governments Receive Less Foreign Aid? American Economic Review, 92, 1126-37.

Anderson, T. W., \& Hsiao, C. (1982). Formulation and Estimation of Dynamic Models Using Panel Data, Journal of Econometrics, 18, 47-82.

Baetschmann, G., Staub, K. E., \& Winkelmann R. (2015). Consistent Estimation of the Fixed Effects Ordered Logit Model. Journal of the Royal Statistical Society, 178, 685-703.

Bernhard, M., Reenock, C., Nordstrom, T. (2004). The Legacy of Western Overseas Colonialism on Democratic Survival. International Studies Quarterly, 48, 225-250.

Birch, S. (2011). Electoral Malpractice, Oxford: Oxford University Press.

Bishop, S. \& Hoeffler, A. (2016). Free and Fair Elections: A New Database. Journal of Peace Research, 53, 608-616.

Bizzarro, F., Coppedge, M., \& Pemstein D. (2016). Incorporating V-Dem's Uncertainty Estimates in Regressions Analysis, unpublished manuscript, Department of Political Science: University of Notre Dame.

Boix, C., \& Stokes, S. (2003). Endogenous Democratization. World Politics, 55, 517-49.

Bormann, N.-C., \& Golder, M. (2013). Democratic electoral systems around the world, 1946-2011. Electoral Studies, 32, 360-369.

Callen, M., \& Long, J. (2015). Institutional Corruption and Election Fraud: Evidence from a Field Experiment in Afghanistan. American Economic Review, 105, 354-381.

Carothers, T. (2015). Democracy aid at 25: Time to choose. Journal of Democracy, 26(1), 59-73.

Chauvet, L., \& Collier, P. (2009). Elections and Economic Policy in Developing Countries. Economic Policy, 24, 509-550.

Clemens, M. A., Radalet, S., Bhavnani, R., \& Bazzi, S. (2011). Counting Chickens When They Hatch: Timing and the Effects of Aid on Growth. Economic Journal, 122, 590-617.

Charron, N. (2011). Exploring the Impact of Foreign Aid on Corruption: Has the 'Anti-corruption Movement' Been Effective? The Developing Economies, 49, 66-88.

Collier, P., \& Vicente, P. C. (2013). Votes and Violence: Evidence from a Field Experiment in Nigeria. Economic Journal, 124, 327-355.

Coppedge, M., Lindberg, S., Skaaning, S.-E., \& Teorell, J. (2016). Measuring High-Level Democratic Principles using the V-Dem Data. International Political Science Review, 37, 580-593.

DFID. (2013). Business Case: 18 month Cost Extension of the Somaliland Election Programme (SEP), London: Department for International Development U.K. (Retrieved from Somaliland Election Programme: iati.dfid.gov.uk/iati_documents/3787611.odt) .

Dickerson, A., Hole A. R., \& Munford, L. (2014). The Relationship Between Well-Being and Commuting Revisited: Does the Choice of Methodology Matter? Regional Science and Urban Economics, 49, 321-329.

Djankov, S., Montalvo, J., \& Reynal-Querol, M. (2008). The Curse of Aid. Journal of Economic Growth, 13, 169-94.

Doucouliagos, H., \& Paldam, M. (2009): The Aid Effectiveness Literature: The Sad Results of 40 years of Research. Journal of Economic Surveys, 23, 433-461.

Dreher, A. (2006). Does globalization affect growth? Evidence from a new index of globalization. Applied Economics, 38, 1091-1110.

Dreher, A, Nunnenkamp, P. \& Thiele, R. (2008). Does Aid for Education Educate Children? Evidence from Panel Data. World Bank Economic Review, 22, 291-314.

EU Commission. (2014). EU Support to Nigeria's electoral cycle 2011-2015. Brussels: EU Commission.

Finkel, S., Perez-Linan, A., \& Seligson, M. (2007). The Effects of US Foreign Assistance on Democracy Building, 1990-2003. World Politics, 59, 404-39.

Fujiwara, T., \& L. Wantchekon, L. (2013). Can Informed Public Deliberation Overcome Clientelism? Experimental Evidence from Benin. American Economic Journal: Applied Economics, 5, 241-255. 
Gleditsch, K.S., \& Ward, M.D. (2006). Diffusion and the International Context of Democratization. International Organization, 60, 911-33.

Hadenius, A., \& Teorell, J. (2007). Pathways from authoritarianism. Journal of Democracy, 18, 143-57.

Hamilton, L.C. (2013): Statistics with Stata: Updated for Version 12, $8^{\text {th }}$ ed., Boston, MA: Brooks/Cole.

Hoeffler, A., \& Outram, V. (2011). Need, Merit or Self-Interest - What Determines the Allocation of Aid? Review of Development Economics, 15, 237-250.

Hyde, S., \& Marinov, N. (2012). Which Elections Can Be Lost? Political Analysis, 20, 191-210.

Ichino, N., \& Schuendeln, M. (2012). Deterring or Displacing Electoral Irregularities? Spillover Effects of Observers in a Randomized Field Experiment in Ghana. Journal of Politics, 74, 292-307.

Keefer, P. \& Vlaicu, R. (2008). Democracy, Credibility, and Clientelism. Journal of Law, Economics, and Organization, 24, 371-406.

Khan, M. (2013). Bangladesh: Economic Growth in a Vulnerable LAO. In D. C. North, J. J. Wallis, S. B. Webb \& B. Weingast (Eds.), In the Shadow of Violence: Politics, Economics and the Problems of Development (pp. 24-69).Cambridge: Cambridge University Press.

Knack, S. (2004). Does Foreign Aid Promote Democracy? International Studies Quarterly, 48, 251-66.

Knack, S., \& Rahman, A. (2007). Donor Fragmentation and Bureaucratic Quality in Aid Recipients. Journal of Development Economics, 83, 176-97.

Mares, I., Muntean, A., \& Petrova T. (2016). Economic Intimidation in Contemporary Elections: Evidence from Romania and Bulgaria. Government and Opposition, 53, 486-517.

Nickell, S. (1981). Biases in Dynamic Models with Fixed Effects. Econometrica, 49(6), 1417-1426.

Norris, P. (2013). The New Research Agenda Studying Electoral Integrity. Electoral Studies, 32, 563-575.

Norris, P. (2015). Why Elections Fail, Cambridge: Cambridge University Press.

Norris, P. (2017). Strengthening Electoral Integrity, Cambridge: Cambridge University Press.

North, D., Wallis, J.J., Webb, S., \& Weingast B. (2007). Limited Access Orders in the Developing World: A New Approach to the Problems of Development, Policy Research Working Paper 4359, Washington, DC: The World Bank.

North, D., Wallis, J.J., \& Weingast B. (2012). Violence and Social Orders, Cambridge: Cambridge University Press.

OECD (2018). International Development Statistics, Paris: Organisation for Economic Cooperation and Development.

Pemstein, D., Marquardt, K., Tzelgov, E., Wang, Y., \& Miri, F. (2015). The Varieties of Democracy Measurement Model: Latent Variable Analysis for Cross-National and Cross-Temporal ExpertCoded Data, V-Dem Working Paper, 21, Gothenburg: The Varieties of Democracy Institute.

Schedler, A. (2002). The Menu of Manipulation. Journal of Democracy, 13, 36-50.

Scott, J.M., \& Steele, C. (2011). Sponsoring Democracy: The United States and Democracy Aid to the Developing World, 1988-2001. International Studies Quarterly, 55, 47-69.

Stock, J.H., \& Watson, M.W. (2015). Introduction to Econometrics, Harlow: Pearson Education Ltd.

Treisman, D. (2000). The Causes of Corruption: A Cross-National Study. Journal of Public Economics, 76, 399-457.

Tuccinardi, D. (Ed.) (2014). International Obligations for Elections: Guidelines for Legal Frameworks, Stockholm: International IDEA.

Uberti, L.J. (2017). Stata Tip 128: Marginal Effects in Log-Transformed Models. Stata Journal, 17, 774-8.

UNDP (2002). Human Development Report 2002: Deepening Democracy in a Fragmented World, New York, NY: Oxford University Press.

UNDP (2012). Evaluation of UNDP Contribution to Strengthening Electoral Systems and Processes, New York, NY: United Nations Development Programme.

USAID. (2015). Bangladesh Election Support Activities Final Performance Evaluation. Washington, DC: United States Agency for International Development.

V-Dem. (2017). V-Dem Codebook v7, Gothenburg: Varieties of Democracy Project.

World Bank (1997). World Development Report 1997: the State in a Changing World. Washington, DC: World Bank. 
World Bank (2017). World Development Report 2017: Governance and the Law. Washington, DC: World Bank.

Wantchekon, L. (2003). Clientelism and Voting Behaviour: Evidence from a Field Experiment in Benin. World Politics, 55, 399-422.

\section{Appendix A: The OECD Aid Data}

The OECD variable measures net disbursements of gross ODA for 'elections'. Some recipients, such as the Gulf states and Malaysia, are sometimes also providers of aid. Thus, the figures, reported in constant (2015) million US\$, net out any ODA outflows donated by the aid recipient. In any case, the countries that are both aid recipients and donors are very few. At the same time, the figures represent the gross flows of ODA in that they do not net out the recipient's repayments (of principal and interest) to the aid donor. We see no convincing theoretical reason to subtract the repayments from the gross figures. While gross inflows are expected to improve the conduct of elections, we cannot think of any plausible ways in which repayments may reverse the integrity gains achieved during the implementation of an aid-funded project (see Clemens et al., 2011 for a similar discussion). In any case, data on repayments is not available in purpose-disaggregated form.

ODA is defined by the OECD as 'government aid designed to promote the economic development and welfare of developing countries' (OECD, 2018). It includes grants and 'soft' loans from official sources. It does not include transfers from international NGOs and private charities. While electoral assistance such as election monitoring is also provided by private organisations (for instance, international NGOs) most funding for election support is channelled through official donor agencies. In any case, data on private development assistance disaggregated by project purpose is not available.

\section{Appendix C: An Alternative Indicator of Electoral Integrity}

Our core results (Table 3) are qualitatively robust to employing an alternative measure of electoral integrity as the dependent variable - the Freedom House (FH) Electoral Processes index (in lieu of integl and integ2). Since the FH indicator is coded on a 12-point ordinal scale, we specify an ordinal logit model with country FE. It is now well-known that estimating an FE ordered logit model by maximum likelihood leads to biased and inconsistent parameter estimates. Alternative estimators are discussed by Baetschmann et al. (2015), who recommend using the BUC ('Blow-up and Cluster') estimator. To implement BUC, we rely on the Stata code graciously made available by Dickerson et al. (2014).

[Table C1] 
The BUC estimates are reported in Table C1. Since panels with no variation on the dependent variable and singleton panels are dropped, the estimation sample is substantially curtailed in these regressions. Yet, the estimated parameters (which do not admit a straightforward quantitative interpretation) have the expected sign and significance level, and their relative magnitude is consistent with previous findings. We conclude that our earlier results are unlikely to be simply an artefact of using our VDem measures of electoral integrity.

\footnotetext{
${ }^{1}$ For instance, article 21(3) of the Universal Declaration of Human Rights, for instance, stipulates that 'the will of the people shall be the basis of the authority of government; this will shall be expressed in periodic and genuine elections which shall be by universal and equal suffrage and shall be held by secret vote or by equivalent free voting procedures'.

${ }^{2}$ For instance, the Perceptions of Electoral Integrity, or PEI, dataset.

${ }^{3}$ For instance, the NELDA indicators on electoral quality (Hyde \& Marinov, 2012), the Free and Fair Elections variable used by Finkel et al. (2007).

${ }^{4}$ For instance, the Freedom House Electoral Process index.

${ }^{5}$ v2elfrfair asks respondents the following question: 'taking all aspects of the pre-election period, election day, and the postelection process into account, would you consider this national election to be free and fair?'.

${ }^{6}$ See Bishop \& Hoeffler (2016, p. 608) for a similar argument.

${ }^{7}$ We construct an index that is slightly more expansive than V-Dem's own 'clean elections' index (v2xel_frefair), which aggregates over eight component indicators - including, oddly, v2elfrfair (V-Dem, 2017).

${ }^{8}$ In case more than one election is held in the same year, each election is coded separately. The responses are subsequently aggregated to produce an overall rating for the (election) year.

${ }^{9}$ The output of the V-Dem item response model is a distribution of possible true scores, and the reported point estimates are the means of this distribution. Thus, in principle, it is possible to incorporate a measure of uncertainty in the regressions (Bizzarro et al., 2016). In practice, however, we do not do this as our dependent variable is a score obtained from factor analysis rather than a single V-Dem variable. In any case, classical measurement error in the dependent variable leads to higher standard errors but does not induce bias in the OLS estimator (Stock \& Watson, 2015, p. 370).

${ }^{10}$ The uniqueness of each of the 13 variables is always much lower than the usually accepted threshold of 0.6.

${ }^{11}$ v2 elfrfair, in turn, is highly correlated with the PEI index favoured by Norris (2017, p. 104).

${ }^{12}$ See, for instance, the USAID project documents quoted by Finkel et al. (2007, fn. 29).

13 The DAC is the OECD's Development Assistance Committee.

${ }^{14}$ Authors' calculations based on data from the OECD, International Development Statistics, 2018

${ }^{15}$ We also consider alternative specifications such as aid per polling station or the fraction of aid in total election costs. To our best knowledge, however, data on polling stations and election costs are not available across countries and over time.

${ }^{16}$ Aid donors may also deliberately punish the countries committing the most egregious violations by withholding aid (Alesina \& Weder, 2002). If this is the case, omitting the relevant confounders would bias the coefficient on aid upwards. Past studies, however, find that donors give little consideration to recipient merit when allocating aid (Hoeffler \& Outram, 2011). Alternatively, donors may allocate aid resources to the countries where future electoral contests are most likely to be free and fair (Knack, 2004). This pathway would also spuriously generate a positive statistical relationship between aid and integrity. We let the data decide whether the omission of joint determinants of aid and integrity leads to downward or upward bias.

${ }^{17}$ Thus, controlling for these factors explicitly might explain away the influence of ODA spending, leading to posttreatment bias. Thus, in our specifications, we are careful to only control for exogenous institutions - that is, institutional characteristics that are neither the outcome nor the 'inputs' of electoral assistance interventions.

${ }^{18}$ To purge the influence of time-invariant country traits, we choose to use the FE (within-) estimator, rather than the first-difference estimator. Since the average number of elections held in a country during 2002-2015 is four, differencing and lagging the regression equation would leave us with very few observations.

${ }^{19}$ We report standard errors clustered at the country level as we find evidence of country-level heteroskedasticity (the $p$-value of a modified Wald test for group-wise heteroskedasticity is 0.000 ). Since elections do not necessarily take place in the same year across all countries, we assume the residuals to be cross-sectionally independent.

${ }^{20} \mathrm{We}$ also experimented with a second lag of ODA, but its estimated coefficient is statistically insignificant.
} 


\footnotetext{
${ }^{21}$ We also estimated model 3 (Table 3) using v2 elfrfair and the simple arithmetic mean of the 13 component indicators as the dependent variable (integrity). The coefficient on (the first lag of) ODA is $0.030(0.018)$ in a regression for integrity and $0.058(0.017)$ in a regression for $v 2$ elfrfair.

${ }^{22}$ That is, a 100 per cent increase in aid.

${ }^{23}$ If the aid-integrity relationship has the following functional form: $I_{i t}=\alpha_{0} \ln O D A_{i t}^{\text {elect }}$, the effect of the marginal dollar is $\partial I_{i t} / \partial O D A_{i t}^{\text {elect }}=a_{0} / O D A_{i t}^{\text {elect }}$. See Uberti (2017) for a discussion of the computation procedure in Stata. ${ }^{24}$ This is a country receiving 5.6 million US\$ in electoral assistance during election years, and 3.7 million US\$ in preelection years. These averages are based on the 460 observations used in the regression.

${ }^{25}$ Results available upon request.

${ }^{26}$ Wooldridge's LM test for autocorrelation in panel data rejects the null that there is no first-order autocorrelation when the dependent variable is integl $(p$-value $=0.002)$ but cannot reject the null at conventional levels when the dependent variable is integ2 $(p$-value $=0.139)$.

${ }^{27}$ For the dynamic model $\left(I_{i t}=\varphi_{0}+\varphi_{1} I_{i t-1}+\alpha_{0} \ln O D A_{i t}^{\text {elect }}+\alpha_{1} \ln O D A_{i t-1}^{\text {elect }}\right)$, the long-run effect of the marginal dollar is given by $\partial I_{i t} / \partial O D A_{i t}^{\text {elect }}=\left[\left(\alpha_{0}+\alpha_{1}\right) /\left(1-\varphi_{1}\right)\right] \cdot\left(1 / O D A_{i t}^{\text {elect }}\right)$. To derive this expression, note that if $t \rightarrow \infty$, then $t=t-1$.

${ }^{28}$ Similar results are obtained by proxying the level of development using the UNDP's Human Development Index.

${ }^{29}$ The full results are available upon request.

${ }^{30} \mathrm{We}$ did not find the effect of ODA spending on integ2 to depend significantly on the level of development. Full results available upon request.

${ }^{31}$ To sift out the effects on integrity of an exogenous change in aid expenditure today and last year, we would need two highly relevant and uncorrelated instruments (Stock \& Watson, 2015, p. 485). We do not have two such instruments

${ }^{32}$ In Model 5 (Panel A), the coefficient on the first lag of ODA loses statistical significance at conventional levels ( $p$ value $=0.124)$.

${ }_{33}^{33}$ Donors should also consider prioritising election-year interventions, which are estimated to have a marginally larger impact than interventions implemented in pre-election years. In any case, most (51.4\%) election-support ODA is already disbursed during or immediately prior to an election, and the remaining 48.6 per cent in years preceding an election (see section 3).
} 


\begin{tabular}{|c|c|c|c|}
\hline Dimension & Integrity Norm & Norm Violation & Example of Intervention \\
\hline \multirow{4}{*}{$\begin{array}{l}\text { Agents } \\
\text { (institutions and } \\
\text { organisations) }\end{array}$} & $\begin{array}{l}\text { - Elective offices are open to political } \\
\text { competition }\end{array}$ & $\begin{array}{l}\text { - Top jobs effectively insulated from electoral } \\
\text { competition }\end{array}$ & - Lifting party bans and civil liberty restrictions \\
\hline & $\begin{array}{l}\text { - Freedom to establish political } \\
\text { organisations and contest an election }\end{array}$ & $\begin{array}{l}\text { - Access to electoral arena is restricted } \\
\text { - Candidatures are arbitrarily rejected }\end{array}$ & $\begin{array}{l}\text {-Election law reform } \\
\text { - Promoting inter-party dialogue and } \\
\text { cooperation } \\
\text { - Establishing dispute resolution mechanisms }\end{array}$ \\
\hline & $\begin{array}{l}\text { - Freedom to learn about, join and } \\
\text { support political organisations }\end{array}$ & $\begin{array}{l}\text { - Media freedom and other civil liberties } \\
\text { restricted or denied } \\
\text { - Unequal access to broadcast media }\end{array}$ & $\begin{array}{l}\text { - Training of media practitioners } \\
\text { - Media law reform }\end{array}$ \\
\hline & $\begin{array}{l}\text { - Level playing field in electoral } \\
\text { competition }\end{array}$ & $\begin{array}{l}\text { - Contestants deprived of } \\
\text { organizational/financial resources } \\
\text { - Unfair campaign financing practices }\end{array}$ & $\begin{array}{l}\text { - Training of political and community leaders } \\
\text { - Campaign finance laws } \\
\text { - Auditing of campaign spending }\end{array}$ \\
\hline \multirow[t]{2}{*}{$\begin{array}{l}\text { Political } \\
\text { preferences }\end{array}$} & - Freedom to cast ballot & $\begin{array}{l}\text { - Vulnerable groups (for instance, women) are } \\
\text { effectively disenfranchised. } \\
\text { - Some voters cannot easily register to vote or } \\
\text { they do not have physical access to the polling } \\
\text { stations }\end{array}$ & $\begin{array}{l}\text { - Support to Electoral Management Bodies } \\
\text { (EMB) } \\
\text { - Affirmative action laws and measures } \\
\text { - Voters education and sensitization campaigns }\end{array}$ \\
\hline & $\begin{array}{l}\text { - Freedom to cast ballot according to } \\
\text { individual preferences }\end{array}$ & $\begin{array}{l}\text { - Vote buying and voter intimidation } \\
\text { - Group voting or family voting }\end{array}$ & $\begin{array}{l}\text { - Voters education and sensitization campaigns } \\
\text { - Strengthening capacity of civil society to } \\
\text { monitor campaign process }\end{array}$ \\
\hline \multirow[t]{2}{*}{ Outcomes } & - One-citizen, one-vote principle & $\begin{array}{l}\text { - Manipulation of voters roll } \\
\text { - Ballot stuffing; destruction/manipulation of } \\
\text { votes cast } \\
\text { - Vote miscounts; fraudulent aggregation of } \\
\text { votes }\end{array}$ & $\begin{array}{l}\text { - Election monitoring by domestic and } \\
\text { international observers } \\
\text { - Strengthen capacity of electoral commission }\end{array}$ \\
\hline & - Incumbent accepts electoral outcome & - Violent resistance to outcome & $\begin{array}{l}\text { - Establish rules and institutions to manage and } \\
\text { resolve electoral disputes } \\
\text { - Strengthen for a for dispute resolution }\end{array}$ \\
\hline
\end{tabular}

Sources: adapted from Schendler, 2002 


\begin{tabular}{|c|c|c|c|}
\hline Dimension & Variable name & Description & Question \\
\hline \multirow[t]{5}{*}{ Agents } & v2elmulpar & Multiparty elections & - Was this national election multiparty? \\
\hline & v2elpdcamp & Access to media (candidates) & $\begin{array}{l}\text { - In this national election, were parties or } \\
\text { candidates able to run paid campaign ads on } \\
\text { national broadcast media? }\end{array}$ \\
\hline & v2elpaidig & Access to media (interest groups) & $\begin{array}{l}\text { - In this election, were interest groups and } \\
\text { individuals able to run paid campaign ads on } \\
\text { national broadcast media? }\end{array}$ \\
\hline & v2elfrcamp & Free campaign media & $\begin{array}{l}\text { - In this national election, did parties or } \\
\text { candidates receive either free or publicly financed } \\
\text { access to national broadcast media? }\end{array}$ \\
\hline & v2elboycot & Election boycotts & $\begin{array}{l}\text { - In this national election, did any registered } \\
\text { opposition candidates or parties boycott the } \\
\text { election? }\end{array}$ \\
\hline \multirow[t]{5}{*}{$\begin{array}{l}\text { Political } \\
\text { preferences }\end{array}$} & v2elembaut & EMB autonomy & $\begin{array}{l}\text { - Does the EMB have autonomy from government } \\
\text { to apply election laws and administrative rules } \\
\text { impartially in national elections? }\end{array}$ \\
\hline & v2elembcap & EMB capacity & $\begin{array}{l}\text { - Does the EMB have sufficient staff and resources } \\
\text { to administer a well-run national election? }\end{array}$ \\
\hline & v2elrgstry & Voter registry & $\begin{array}{l}\text { - In this national election, was there a reasonably } \\
\text { accurate voter registry in place and was it used? }\end{array}$ \\
\hline & v2elvotbuy & Vote-buying & $\begin{array}{l}\text { - In this national election, was there evidence of } \\
\text { vote and/or turnout buying? }\end{array}$ \\
\hline & v2elintim & Government intimidation & $\begin{array}{l}\text { - In this national election, were opposition } \\
\text { candidates/parties/campaign workers subjected } \\
\text { to repression, intimidation, violence, or } \\
\text { harassment by the government, the ruling party, } \\
\text { or their agents? }\end{array}$ \\
\hline \multirow[t]{3}{*}{ Outcomes } & v2elirreg & Voting irregularities & $\begin{array}{l}\text { - In this national election, was there evidence of } \\
\text { other intentional irregularities by incumbent } \\
\text { and/or opposition parties, and/or vote fraud? }\end{array}$ \\
\hline & v2elaccept & Acceptance of election results & $\begin{array}{l}\text { - Did losing parties and candidates accept the } \\
\text { result of this national election within three } \\
\text { months? }\end{array}$ \\
\hline & v2elpeace & Electoral violence (non-governmental) & $\begin{array}{l}\text { - In this national election, was the campaign } \\
\text { period, election day, and postelection process free } \\
\text { from other types (not by the government, the } \\
\text { ruling party, or their agents) of violence related to } \\
\text { the conduct of the election and the campaigns } \\
\text { (but not conducted by the government and its } \\
\text { agents)? }\end{array}$ \\
\hline
\end{tabular}

Sources: V-Dem, 2017. 
FIGURE 1: Partial correlations between the factor scores (integ1, integ2) and the V-Dem variables

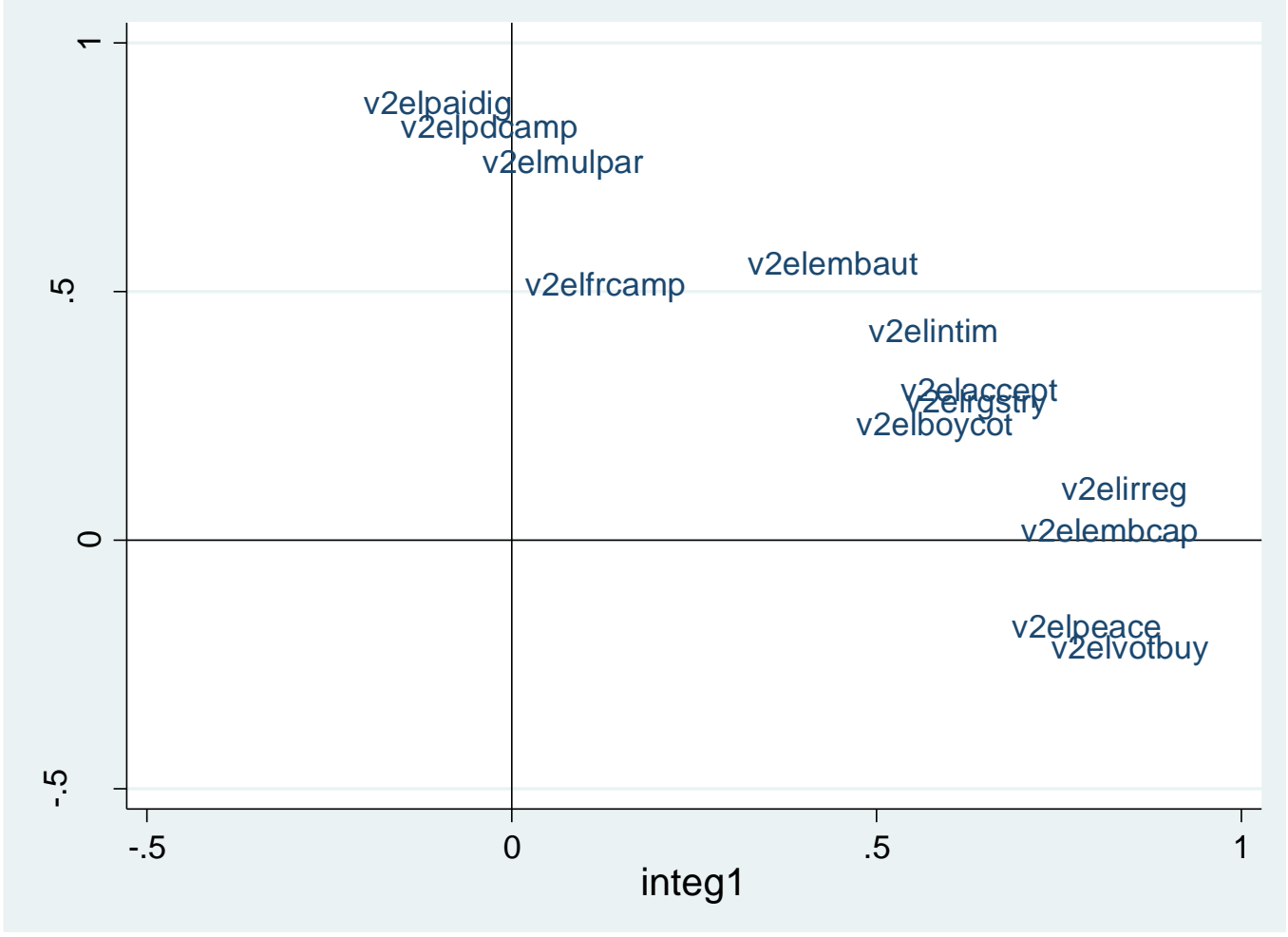

Sources: author's calculations based on data from V-DEM Project. Notes: the factor scores and loadings are based on a principal-component method and an oblique promax rotation.

FIGURE 2: ODA spending on elections and electoral integrity outcomes, 2002-2015

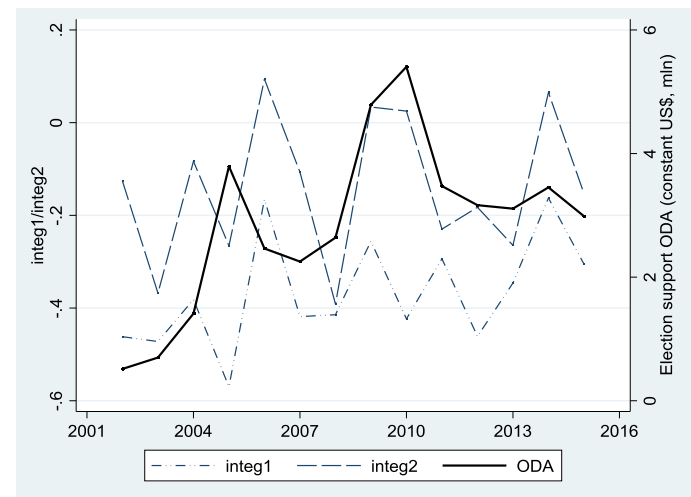


(1)

Panel A - Dependent variable: integ1

Election support ODA, log

Election support ODA, log - Lag (1 year)

$\begin{array}{ccc}-0.074 * * * & 0.031^{* * *} & 0.021 * \\ (0.018) & (0.011) & (0.012) \\ & & 0.020^{* * *} \\ & & (0.007)\end{array}$

Election support ODA per capita, log

R-squared

Panel A - Dependent variable: integ2

Election support ODA, log

$0.047^{* *}$

(0.024)

Election support ODA, log - Lag (1 year)

Election support ODA per capita, log

R-squared

Country FE

N. of elections (observations)

N. of countries (groups)

Notes: the dependent variable is electoral integrity; robust standard errors clustered at the country level are reported in parentheses; $* * * p<0.01, * * p<0.05, * p<0.1$. The R-squared is for 'within' variation in the models with country FE.

\section{FIGURE 3: Partial correlation plot: election support ODA and electoral integrity}

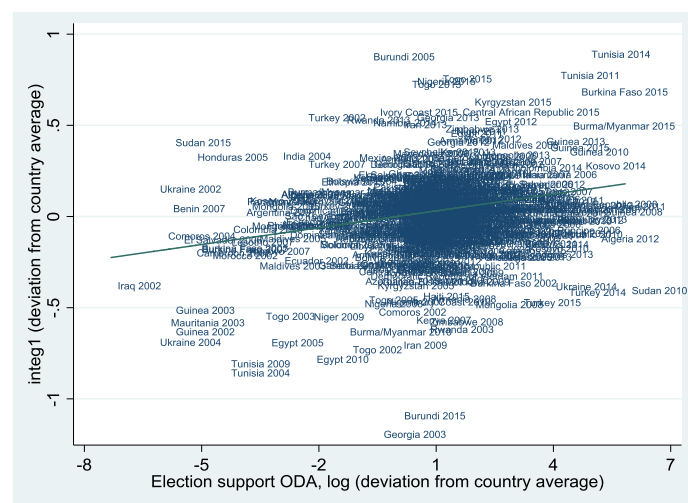

Notes: country average during 2002-2015. Based on Table 3, model 2.
(24.52)

0.03

$93.13 * * *$

(29.61)

0.04

Yes

486

$460 \quad 486$

126

4) 
FIGURE 4: Estimated effect of election support ODA on electoral integrity

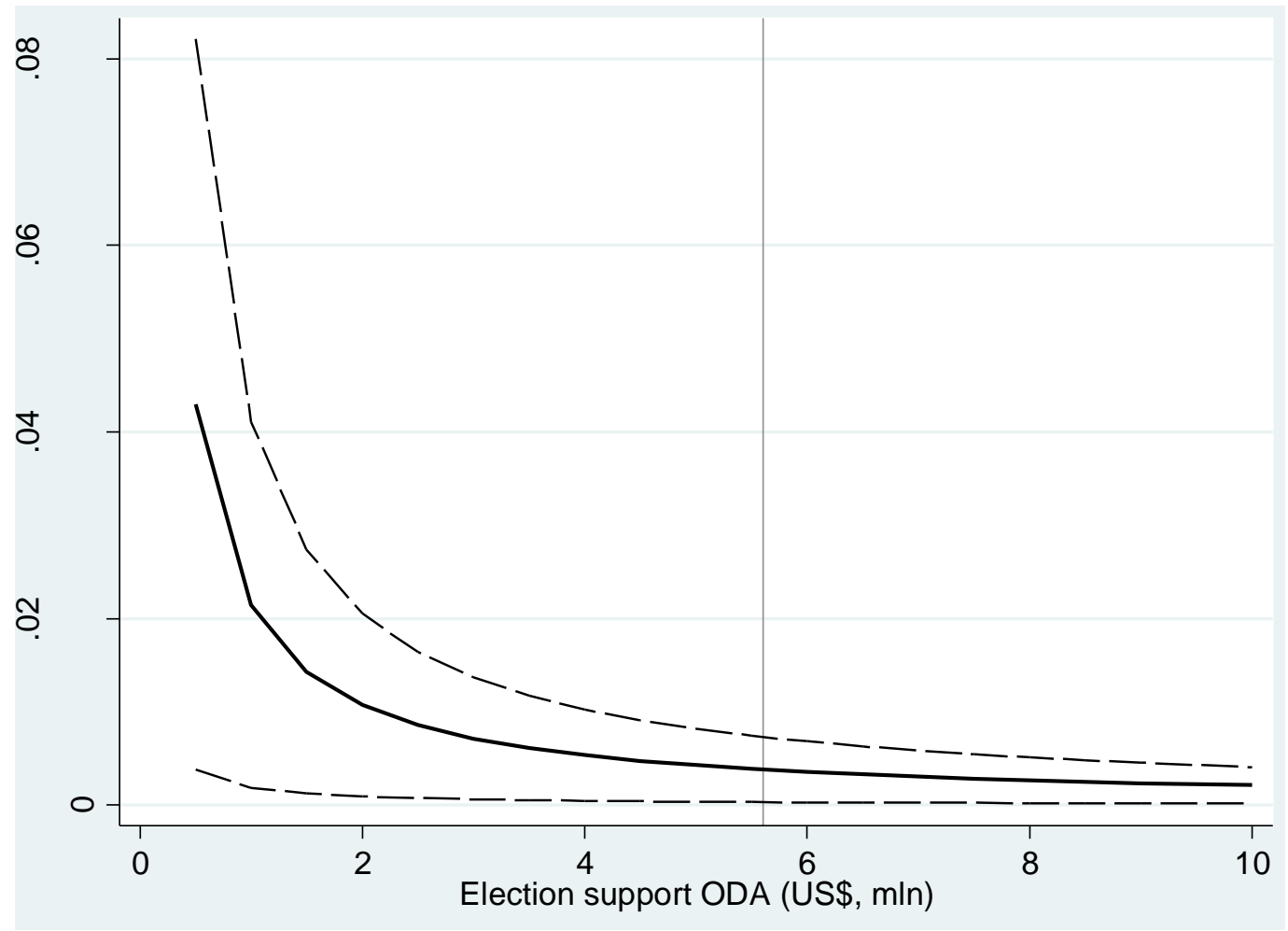

Notes: based on Table 2, model 3. The diagram plots the marginal effect of election-year ODA spending on the electoral integrity index, at different levels of aid spending. The dashed lines mark the 95 per cent confidence interval. The vertical line denotes the average value of ODA spending (5.6 mln US\$). The standard deviation of the integrity index is 0.81

TABLE 4: Effects of ODA spending for election support on components of electoral integrity

\begin{tabular}{llllll} 
Dependent variable: & \multicolumn{2}{l}{ Election support ODA } & \multicolumn{2}{l}{ Election support ODA, lag } & R2 \\
\hline integ1 & $0.021^{*}$ & $(0.012)$ & $0.021^{* * *}$ & $(0.007)$ & 0.08 \\
Government intimidation & $0.052^{*}$ & $(0.027)$ & 0.015 & $(0.010)$ & 0.07 \\
Voting irregularities & $0.047^{* *}$ & $(0.021)$ & $0.032^{* *}$ & $(0.015)$ & 0.09 \\
Vote-buying & $0.032^{* *}$ & $(0.013)$ & $0.019^{* *}$ & $(0.009)$ & 0.06 \\
Voter registry & $0.027^{*}$ & $(0.016)$ & 0.012 & $(0.011)$ & 0.03 \\
Acceptance of election results & 0.026 & $(0.021)$ & $0.023^{*}$ & $(0.014)$ & 0.03 \\
EMB capacity & 0.018 & $(0.013)$ & 0.009 & $(0.007)$ & 0.03 \\
Election boycotts & 0.016 & $(0.018)$ & 0.023 & $(0.015)$ & 0.02 \\
Electoral violence (non-gov't) & -0.006 & $(0.014)$ & $0.026^{*}$ & $(0.014)$ & 0.01 \\
\hline integ2 & $0.034^{* *}$ & $(0.014)$ & $0.012^{* *}$ & $(0.005)$ & 0.10 \\
EMB autonomy & $0.058^{* * *}$ & $(0.021)$ & $0.036^{* * *}$ & $(0.008)$ & 0.19 \\
Access to media (interest groups) & $0.040^{* * *}$ & $(0.012)$ & -0.001 & $(0.009)$ & 0.05 \\
Access to media (candidates) & $0.029^{* *}$ & $(0.013)$ & 0.009 & $(0.008)$ & 0.04 \\
Free campaign media & 0.027 & $(0.022)$ & $0.016^{*}$ & $(0.009)$ & 0.03 \\
Multiparty elections & 0.022 & $(0.022)$ & $0.021^{* *}$ & $(0.010)$ & 0.03 \\
\hline
\end{tabular}

Notes: the reported coefficients are for OLS models with country FE along the lines of Table 3, models 3 (also reproduced here); robust standard errors clustered at the country level are reported in parentheses; $* * * \mathrm{p}<0.01, * * \mathrm{p}<0.05, * \mathrm{p}<0.1$. 


\begin{tabular}{|c|c|c|c|c|}
\hline & $\begin{array}{c}\text { OLS-stat } \\
\text { (1) }\end{array}$ & $\begin{array}{c}\text { OLS-dyn } \\
(2)\end{array}$ & $\begin{array}{c}I V-2 S L S \\
(3)\end{array}$ & $\begin{array}{c}\text { OLS-trend } \\
\text { (4) }\end{array}$ \\
\hline \multicolumn{5}{|l|}{ Panel A - Dependent variable: integ1 } \\
\hline Electoral integrity - previous contest & & $\begin{array}{c}0.298 * * * \\
(0.074)\end{array}$ & $\begin{array}{c}0.331 \\
(0.239)\end{array}$ & \\
\hline Election support ODA, log & $\begin{array}{l}0.023^{*} \\
(0.012)\end{array}$ & $\begin{array}{l}0.020^{*} \\
(0.010)\end{array}$ & $\begin{array}{l}0.019 * \\
(0.011)\end{array}$ & $\begin{array}{l}0.029 * * \\
(0.014)\end{array}$ \\
\hline Election support ODA, log - Lag (1 year) & $\begin{array}{c}0.019 * * * \\
(0.007)\end{array}$ & $\begin{array}{c}0.018^{* * *} \\
(0.007)\end{array}$ & $\begin{array}{c}0.018^{* * *} \\
(0.007)\end{array}$ & $\begin{array}{c}0.014 \\
(0.009)\end{array}$ \\
\hline R-squared & 0.08 & 0.16 & - & 0.63 \\
\hline Kleibergen-Paap rk Wald F-stat & & & 25.3 & \\
\hline Stock-Yogo critical value (10\%) & & & 16.4 & \\
\hline \multicolumn{5}{|l|}{ Panel A - Dependent variable: integ 2} \\
\hline Electoral integrity - previous contest & & $\begin{array}{c}0.293 * * * \\
(0.103)\end{array}$ & $\begin{array}{c}0.364 * * \\
(0.172)\end{array}$ & \\
\hline Election support ODA, log & $\begin{array}{c}0.035^{* *} \\
(0.014)\end{array}$ & $\begin{array}{c}0.030^{* *} \\
(0.012)\end{array}$ & $\begin{array}{l}0.028^{* *} \\
(0.012)\end{array}$ & $\begin{array}{l}0.031^{* *} \\
(0.015)\end{array}$ \\
\hline Election support ODA, log - Lag (1 year) & $\begin{array}{l}0.010^{*} \\
(0.005)\end{array}$ & $\begin{array}{c}0.006 \\
(0.005)\end{array}$ & $\begin{array}{c}0.005 \\
(0.006)\end{array}$ & $\begin{array}{l}0.019 * * \\
(0.008)\end{array}$ \\
\hline R-squared & 0.10 & 0.19 & - & 0.68 \\
\hline Kleibergen-Paap rk Wald F-stat & & & 27.1 & \\
\hline Stock-Yogo critical value (10\%) & & & 16.4 & \\
\hline Country FE & Yes & Yes & Yes & Yes \\
\hline Country-specific trends and time FE & No & No & No & Yes \\
\hline N. of elections (observations) & 435 & 435 & 435 & 435 \\
\hline N. of countries (groups) & 116 & 116 & 116 & 116 \\
\hline
\end{tabular}

Notes: the dependent variable is electoral integrity. Robust standard errors clustered at the country level are reported in parentheses; ${ }^{* * *} p<0.01,{ }^{* *} p<0.05, * p<0.1$; constant not reported to save space. Model 3 instruments for the first lag of electoral integrity (integrity of last contest) using the second lag (integrity of next-to-last contest). Model 4 includes country-specific trend terms and time-period dummies. 


\begin{tabular}{|c|c|c|c|c|c|c|}
\hline & (1) & (2) & (3) & (4) & (5) & (6) \\
\hline \multicolumn{7}{|l|}{ Panel A - Dependent variable: integ1 } \\
\hline \multirow[t]{2}{*}{ Election support aid, log } & $0.024^{* *}$ & $0.024^{* *}$ & 0.018 & $0.023^{*}$ & 0.032 & 0.030 \\
\hline & $(0.012)$ & $(0.012)$ & $(0.012)$ & $(0.012)$ & $(0.022)$ & $(0.022)$ \\
\hline \multirow{2}{*}{ Election support aid, log - Lag (1 year) } & $0.018 * * *$ & $0.018 * * *$ & $0.021 * * *$ & $0.015^{* *}$ & $0.034 * * *$ & $0.033^{* * *}$ \\
\hline & $(0.007)$ & $(0.007)$ & $(0.007)$ & $(0.006)$ & $(0.011)$ & $(0.011)$ \\
\hline Wald test (Time FE $=0)[p$-value $]$ & {$[0.321]$} & [0.304] & {$[0.194]$} & [0.226] & [0.239] & [0.171] \\
\hline R-squared & 0.16 & 0.16 & 0.18 & 0.18 & 0.29 & 0.22 \\
\hline \multicolumn{7}{|l|}{ Panel A - Dependent variable: integ2 } \\
\hline \multirow[t]{2}{*}{ Election support aid, log } & $0.045^{* * *}$ & $0.045^{* * *}$ & $0.037 * *$ & $0.040 * * *$ & 0.037 & 0.035 \\
\hline & $(0.015)$ & $(0.014)$ & $(0.014)$ & $(0.014)$ & $(0.026)$ & $(0.025)$ \\
\hline \multirow[t]{2}{*}{ Election support aid, log - Lag (1 year) } & $0.014 * *$ & $0.014^{* * *}$ & $0.013^{* *}$ & $0.011^{*}$ & $0.018^{*}$ & 0.017 \\
\hline & $(0.005)$ & $(0.005)$ & $(0.006)$ & $(0.005)$ & $(0.010)$ & $(0.010)$ \\
\hline Wald test (Time FE $=0)[p$-value $]$ & {$[0.033]$} & [0.068] & {$[0.059]$} & [0.104] & {$[0.010]$} & {$[0.056]$} \\
\hline R-squared & 0.17 & 0.17 & 0.19 & 0.20 & 0.29 & 0.18 \\
\hline Structural constraints & No & Yes & No & No & Yes & No \\
\hline Other international forces & No & No & Yes & No & Yes & No \\
\hline Domestic institutions & No & No & No & Yes & Yes & No \\
\hline Country FE & Yes & Yes & Yes & Yes & Yes & Yes \\
\hline Time FE & Yes & Yes & Yes & Yes & Yes & Yes \\
\hline N. of elections (observations) & 436 & 436 & 409 & 419 & 204 & 204 \\
\hline N. of countries (groups) & 121 & 121 & 124 & 117 & 57 & 57 \\
\hline
\end{tabular}

FIGURE 5: Effects of aid on integrity (integ1) at different levels of development

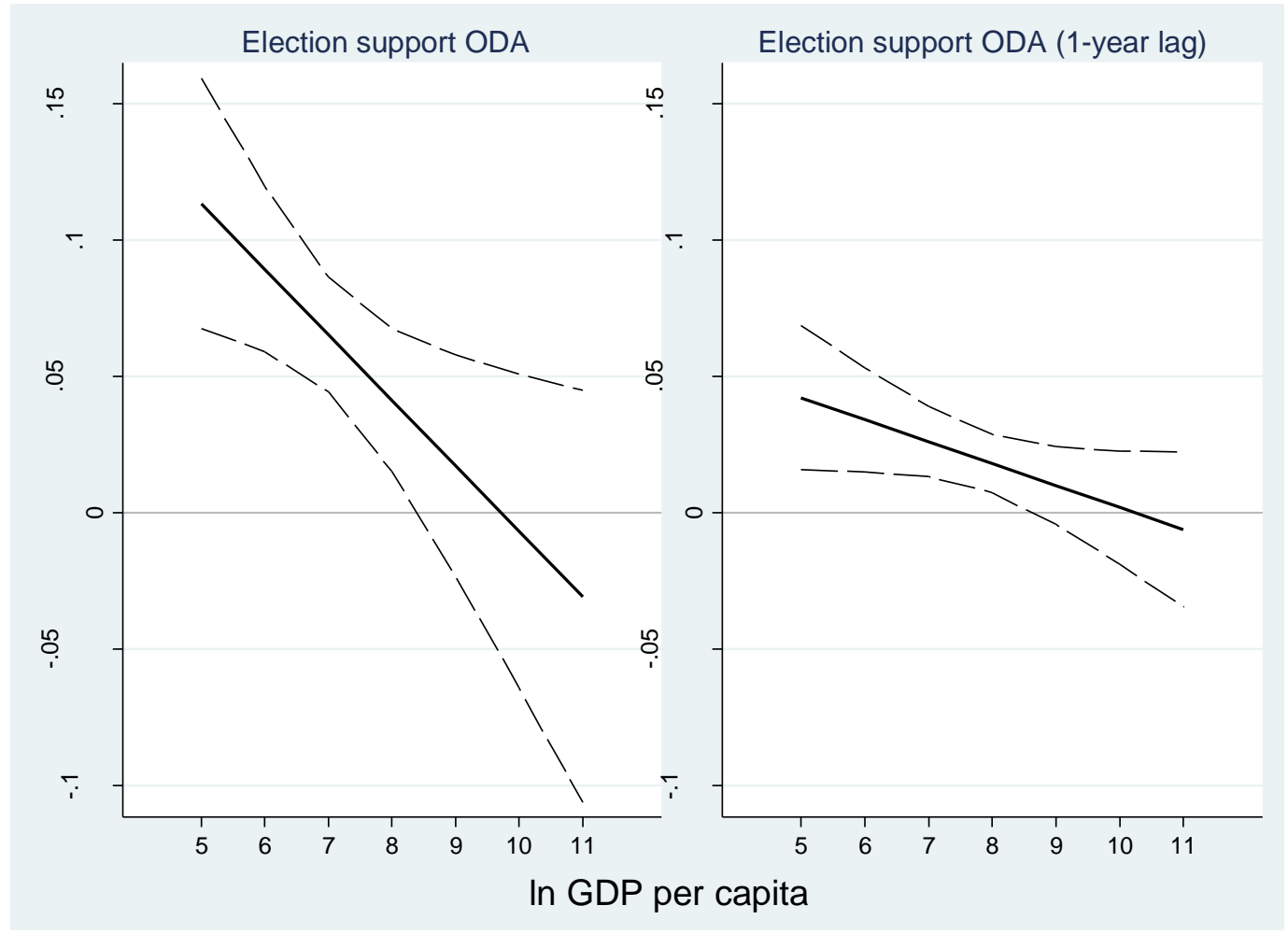


TABLE 7: Robustness Analysis -Instrumental Variable (IV) Models with Country FE

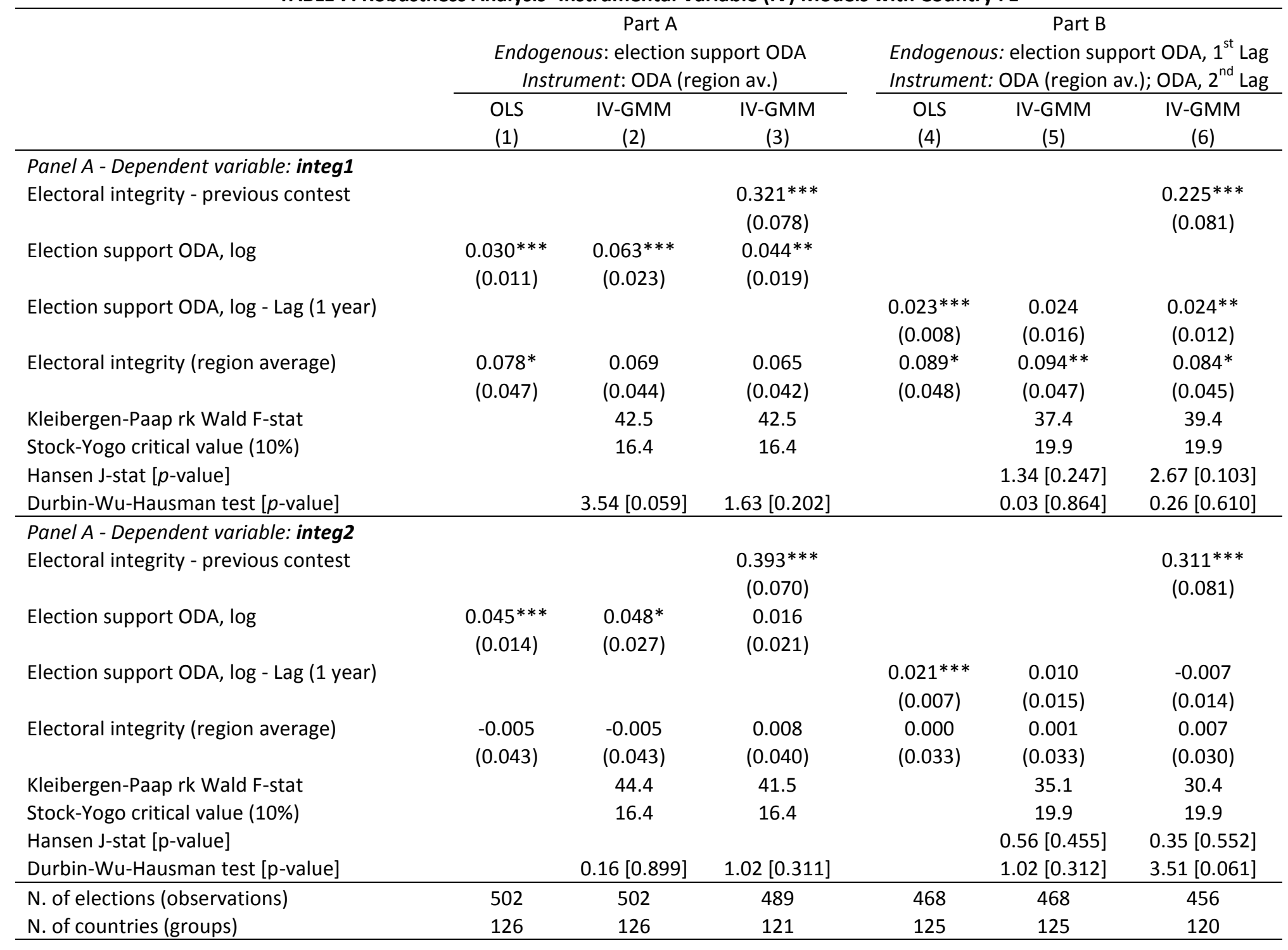

Notes: the dependent variable is electoral integrity. All models include country FE. Robust standard errors clustered at the country level are reported in parentheses; $* * * p<0.01, * * p<0.05, * p<0.1$. The coefficients of the IV models are obtained with a two-step optimal GMM estimator. 


\begin{tabular}{lll} 
Variable & Code & Description \\
\hline $\begin{array}{l}\text { Election support } \\
\text { ODA }\end{array}$ & In_aidelect & $\begin{array}{l}\text { Aid for 'electoral management bodies and } \\
\text { processes, election observation and voters' } \\
\text { education' (OECD budget code 15151), in log }\end{array}$ \\
$\begin{array}{lll}\text { Election support } \\
\text { ODA per capita }\end{array}$ & In_aidelectpc & $\begin{array}{l}\text { Election support ODA divided by mid-year } \\
\text { population, in logs }\end{array}$
\end{tabular}

Electoral Integrity integrity

Electoral integrity fh_ep

(alternative)

GDP per capita

In_gdppc

Oil Rents, \% GDP

In_oil

HDI

Political

Globalisation

Index (KOF)

Average of 13 indicators of electoral quality

Electoral Process index measuring to what and graded between 0 (worst) and 12 (best).

log of GDP per capita, constant 2010 US\$

Oil rents as a share of GDP, in logs. Oil rents of production.

Human Development Index international organizations of which the extent the national legislative representatives

the national chief authority are elected through free and fair elections. Countries are are the difference between the value of crude oil production at world prices and total costs

Index measuring the number of embassies and high commissions in a country, the number of country is a member, the number of UN peace missions the country has participated in, and the number of international treaties that the country has signed since 1945 .

Electoral Integrity (region av.)

Western

observes

Executive years dpi_yio

in office

N. of years since independence e_observe

integrity region Average level of electoral integrity in geopolitical region (excluding own country). The geo-political units are: Eastern Europe, Asia, Sub-Saharan Africa, Latin America, Middle East and North Africa (MENA).

Coded as 1 if international monitors are primarily from Western countries or Western international organisations (NELDA 46)

Number of years since the chief executive has been in office.

years_since_ind

Number of years since state became (de facto) independent
Source

$\mathrm{OECD}$, International

Development Statistics, 2018

Authors' construction based on OECD, International Development Statistics, 2018; World Bank, World Development Indicators, 2018 Varieties of Democracy (VDem) Project, version 7.2

Freedom House, Freedom in the World, 2018

World Bank, World Development Indicators, 2018

World Bank, World Development Indicators, 2019

United Nations

Development Programme, Human Development Report 2016, 2017

Dreher, 2006

Authors' construction based on integrity

Hyde \& Marinov, 2012

Inter-American Development Bank, Database of Political Instituitons, 2016 Hensel, ICOW Colonial History Dataset, 2014 
Measures the degree to which 'fair and predictable rules form the basis for economic and social interactions and the extent to which property rights are protected'.

Geopolitical ht_region regions
Categorical variable for Eastern Europe and Post-Soviet Union, Latin America, MENA region, Sub-Saharan Africa, Asia, The Pacific.
World Bank, Worldwide Governance Indicators, 2010

Hadenius \& Teorell, 2007

TABLE C1: Robustness analysis - Alternative measures of electoral integrity (Freedom House)

\begin{tabular}{lccc} 
& BUC & BUC & BUC \\
& $(1)$ & $(2)$ & $(3)$ \\
\hline Election support ODA, log & & & \\
& $0.212^{* *}$ & & 0.155 \\
Election support ODA, log - Lag (1 year) & $(0.091)$ & & $(0.098)$ \\
& & $0.171^{* *}$ & $0.122^{*}$ \\
& & $(0.070)$ & $(0.067)$ \\
Country FE & & & \\
N. of elections (observations) & Yes & Yes & Yes \\
N. of countries (groups) & 240 & 240 & 240 \\
Pseudo R-Squared (within) & 68 & 68 & 68 \\
\hline
\end{tabular}

Notes: FE ordered logit regressions based on the BUC ("Blow-up and Cluster") estimator.

Robust standard errors clustered at the country level are reported in parentheses; ${ }^{* *} p<0.01$, $* * p<0.05, * p<0.1$ 